Supporting Information

\title{
Molecular Valence Tautomeric Metal Complexes for Chemosensing
}

\author{
Max Mörtel, ${ }^{a}$ Johannes Oschwald, ${ }^{b}$ Andreas Scheurer, ${ }^{a}$ Thomas Drewello, ${ }^{b}$ \\ and Marat M. Khusniyarov ${ }^{a *}$
}

${ }^{a}$ Department of Chemistry and Pharmacy

Friedrich-Alexander University Erlangen-Nürnberg (FAU)

Egerlandstraße 1, 91058 Erlangen, Germany

${ }^{b}$ Department of Chemistry and Pharmacy

Friedrich-Alexander University Erlangen-Nürnberg (FAU)

Egerlandstraße 3, 91058 Erlangen, Germany

\section{Corresponding Author}

*E-mail: marat.khusniyarov@fau.de 


\section{Table of Contents}

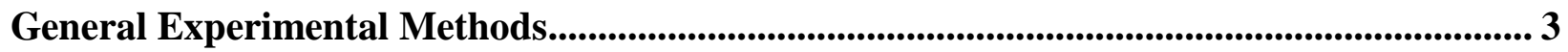

Titration Experiments ............................................................................................................................ 5

Titration with parent ligand: CIVT effect ................................................................ 5

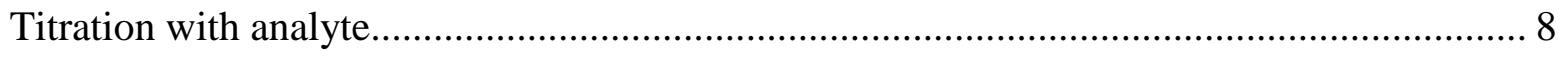

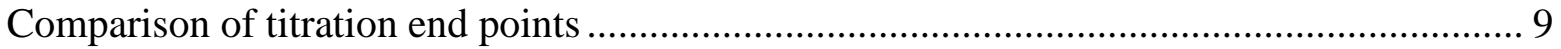

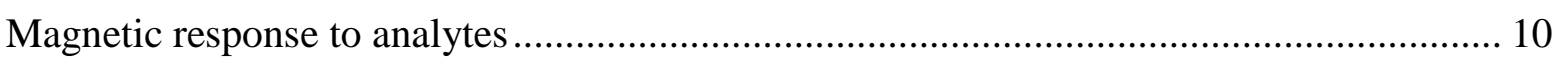

Comparison of fitted parameters ................................................................................ 10

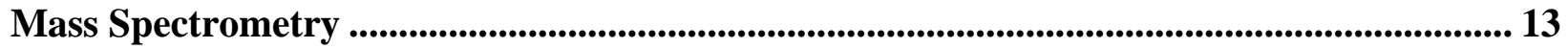

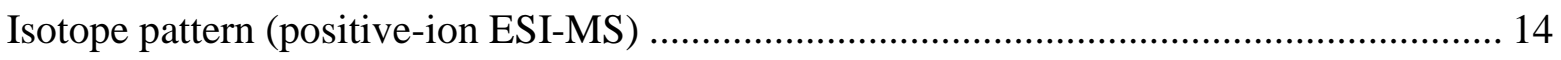

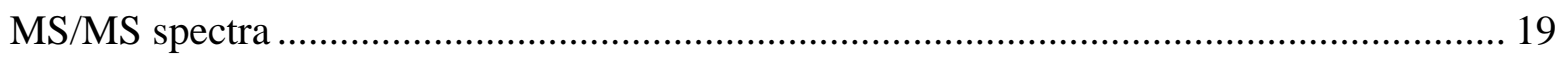

Cyclic Voltammetry .............................................................................................................................. 21

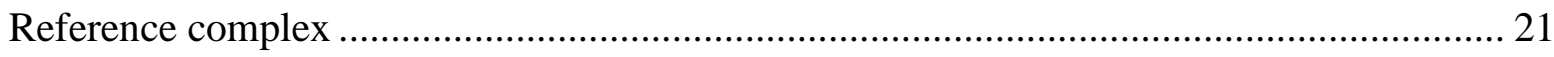

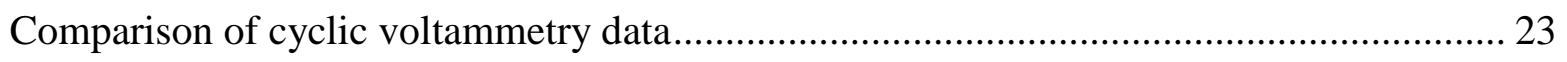

Theoretical Calculations............................................................................................................................. 27

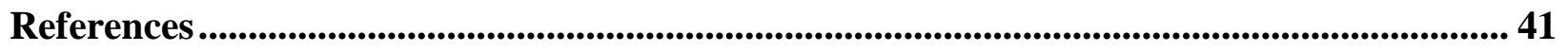




\section{General Experimental Methods}

Materials. All starting materials and solvents were utilized as received without further purification unless otherwise noted. Pure anhydrous solvents were collected from a solid-state solvent purification system Glass Contour (Irvine, CA). Anhydrous DMSO has been purchased from ACROS Organics ${ }^{\circledR}$ (Extra Dry). [Co( $\left.\left({ }^{\mathrm{B}} \mathrm{Bu} \text {-dioxolene }\right)_{2}(\text { stypy })_{2}\right](\mathbf{1}),{ }^{1}\left[\mathrm{Co}\left({ }^{\mathrm{t}} \mathrm{Bu} \text {-dioxolene }\right)_{2}(\mathrm{py})_{2}\right]$ (2), ${ }^{2}$ and trans-4-styrylpyridine (stypy) ${ }^{3}$ were synthesized according to literature methods with minor modifications. Modifications: complexes $\mathbf{1}$ and $\mathbf{2}$ were washed with hexanes and dried in vacuo $\left(1: 80^{\circ} \mathrm{C} ; 2\right.$ : RT) overnight. Purity has been confirmed by elemental analysis and solid-state magnetic measurements.

NMR spectra were recorded at $298 \mathrm{~K}$ with a JEOL ECP $400 \mathrm{MHz}$ in rotating $5 \mathrm{~mm}$ o.d. tubes with a J. Young valve and processed with Delta V4.0 software provided by JEOL Ltd. All solutions have been prepared under inert conditions. Melting point capillary tubes sealed with Weiton ${ }^{\circledR}$ wax were used as inner tubes in EVANS NMR method experiments.

Electronic absorption spectra were recorded at $298.15 \mathrm{~K}$ in sealed custom made Quartz SUPRASIL cells (QS) with a Shimadzu UV 3600 spectrophotometer and a Julabo F10C cryostat with custom-made cooling attachment. All solutions have been prepared under inert conditions.

Electrochemical measurements were performed under nitrogen atmosphere using a standard three-electrode setup with a gc rotating disc electrode (RDE) as working and platinum rods as counter and reference electrodes. The potentiostat was a Metrohm $\mu$ Autolab III/FRA2. All solutions were prepared in $\mathrm{CH}_{2} \mathrm{Cl}_{2}$ containing $0.1 \mathrm{M}{ }^{n} \mathrm{Bu}_{4} \mathrm{NPF}_{6}$ as supporting electrolyte and measured at room temperature. All potentials are referenced to the $\mathrm{Fc}^{+/ 0}$ redox couple measured after adding ferrocene as internal standard to the solution. 
Mass Spectrometry experiments were conducted with a micrOTOF-Q II orthogonal acceleration qToF mass spectrometer (Bruker Daltonics, Bremen, Germany) equipped with an ESI ion source in the positive ion mode. The instrumental settings were adjusted for maximum signal intensity. The ion source parameters were as follows: Heated nitrogen $\left(200^{\circ} \mathrm{C}\right)$ was used as the drying gas at a flux of $4 \mathrm{~L} / \mathrm{min}$. Likewise; nitrogen was used as nebulizing gas at a pressure of $0.4 \mathrm{bar}$. A spray shield voltage of $-500 \mathrm{~V}$ and a capillary voltage of $-4500 \mathrm{~V}$ were applied. Collision-induced dissociation (CID) experiments were conducted with nitrogen as the collision gas. The collision experiments were repeatedly performed on several days assuring the reliability of the data. For collision experiments, the precursor ion was mass selected and accelerated inside the collision quadrupole to the desired laboratory kinetic collision energy.

For the MS experiments, a $5 \cdot 10^{-5} \mathrm{M}$ solution of $\mathbf{1}$ in DCM was prepared and transferred to the mass spectrometer under inert gas atmosphere where the sample was injected by direct infusion with a syringe pump at a flowrate of $180-240 \mu \mathrm{L} / \mathrm{h}$. During the transfer of the solution into the syringe, the sample was briefly exposed to air, which could not be prevented due to the experimental setup. This resulted in a slow side reaction which started to get noticeable after approximately $30 \mathrm{~min}$ of measurement time. This problem was alleviated by preparing multiple sample solutions and storing them under inert gas prior to the analysis.

For the measurements with DMSO and DMSO- $d_{6}$ (Purity 99.9\%), the solution contained 0.5 M ( $10^{4}$ equivalents) of DMSO and DMSO- $d_{6}$, respectively. At lower concentrations almost no change in the spectrum could be observed compared to $\mathbf{1}$ in pure DCM. 


\section{Titration Experiments}

Titration with parent ligand: CIVT effect

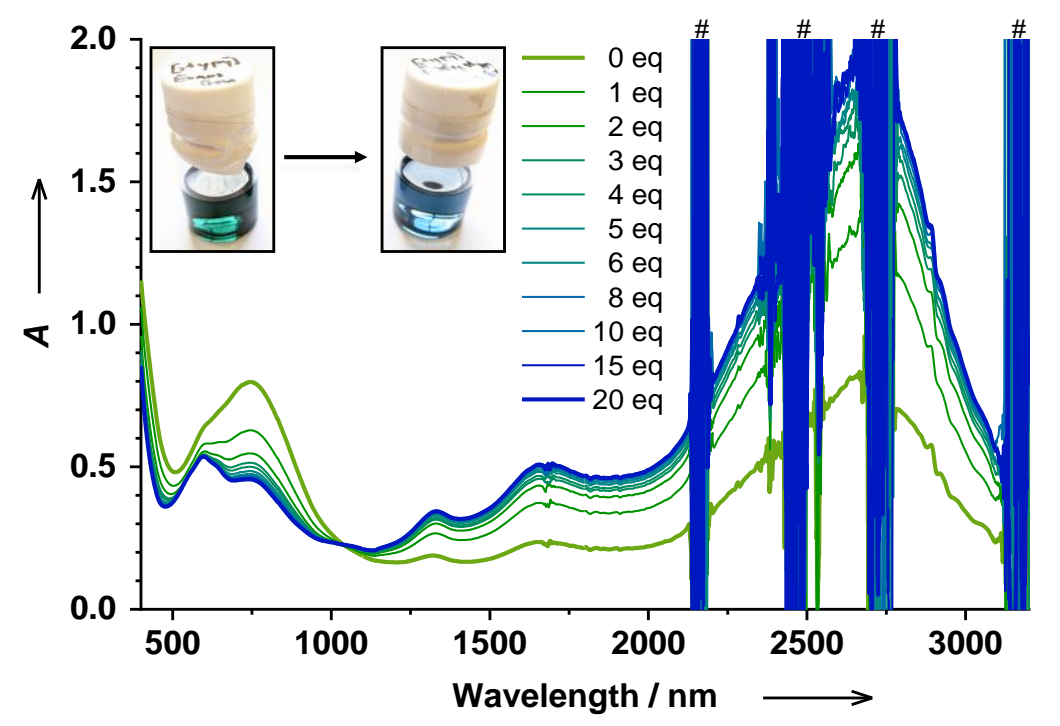

Figure S1: Electronic absorption spectrum of $\left[\mathbf{C o}\left({ }^{t} \mathbf{B u}-\text { dioxolene }\right)_{2}(\mathbf{s t y p y})_{2}\right](\mathbf{1})$ in benzene $\left(c=5 \cdot 10^{-4} \mathrm{M}\right)$ with different amounts of excess stypy. Artefacts (\#) are due to solvent overtones. 


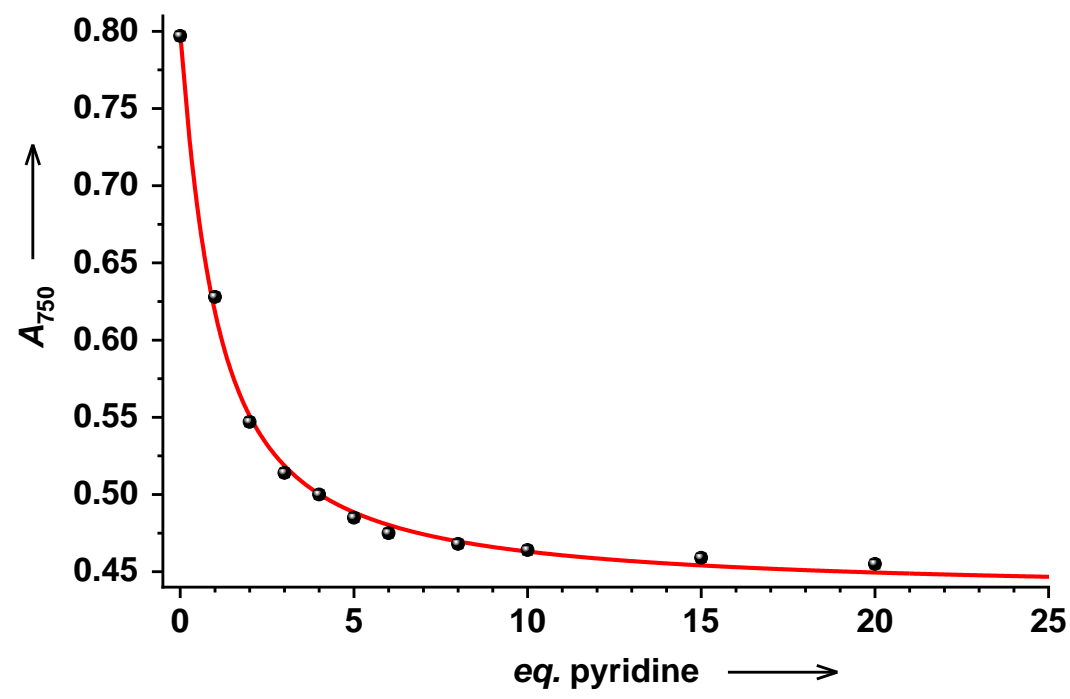

Figure S2: Evolution of the $750 \mathrm{~nm}$ absorption band of $\left[\mathbf{C o}\left({ }^{(} \mathbf{B u} \text {-dioxolene }\right)_{2}(\mathbf{s t y p y})_{2}\right](\mathbf{1})$ in benzene $\left(c=5 \cdot 10^{-4} \mathrm{M}\right)$ with different amounts of excess stypy. Fit parameters: $\varepsilon_{\mathrm{A}}=2.52(6) \cdot 10^{3} \mathrm{M}^{-1} \mathrm{~cm}^{-1}, \varepsilon_{\mathrm{B}}=0.870(7) \cdot 10^{3} \mathrm{M}^{-1} \mathrm{~cm}^{-1}$, $K_{a}=5.7(5) \cdot 10^{3} \mathrm{~L} \mathrm{~mol}^{-1}$.

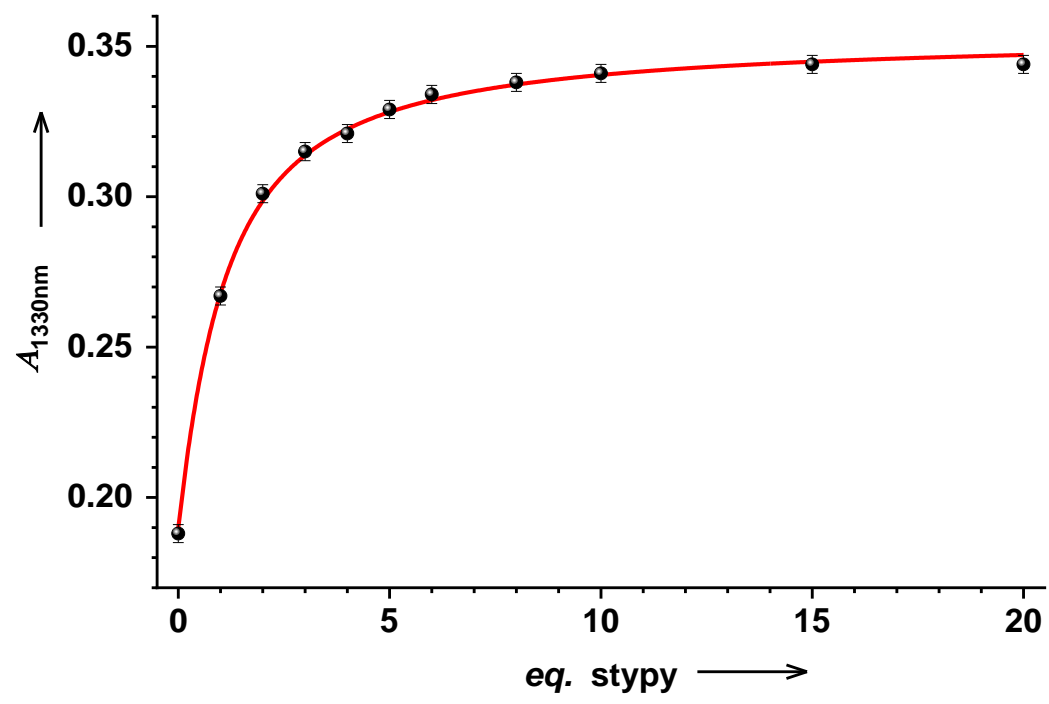

Figure S3: Evolution of the $1330 \mathrm{~nm}$ absorption band of [Co('Bu-dioxolene $\left.)_{2}(\text { stypy })_{2}\right](1)$ in benzene $\left(c=5 \cdot 10^{-4} \mathrm{M}\right)$ with different amounts of excess stypy. Fit parameters: $\varepsilon_{\mathrm{A}}=0 \mathrm{M}^{-1} \mathrm{~cm}^{-1}, \varepsilon_{\mathrm{B}}=0.708(2) \cdot 10^{3} \mathrm{M}^{-1} \mathrm{~cm}^{-1}, K_{a}=5.0(1) \cdot 10^{3}$ $\mathrm{L} \mathrm{mol}^{-1}$. 


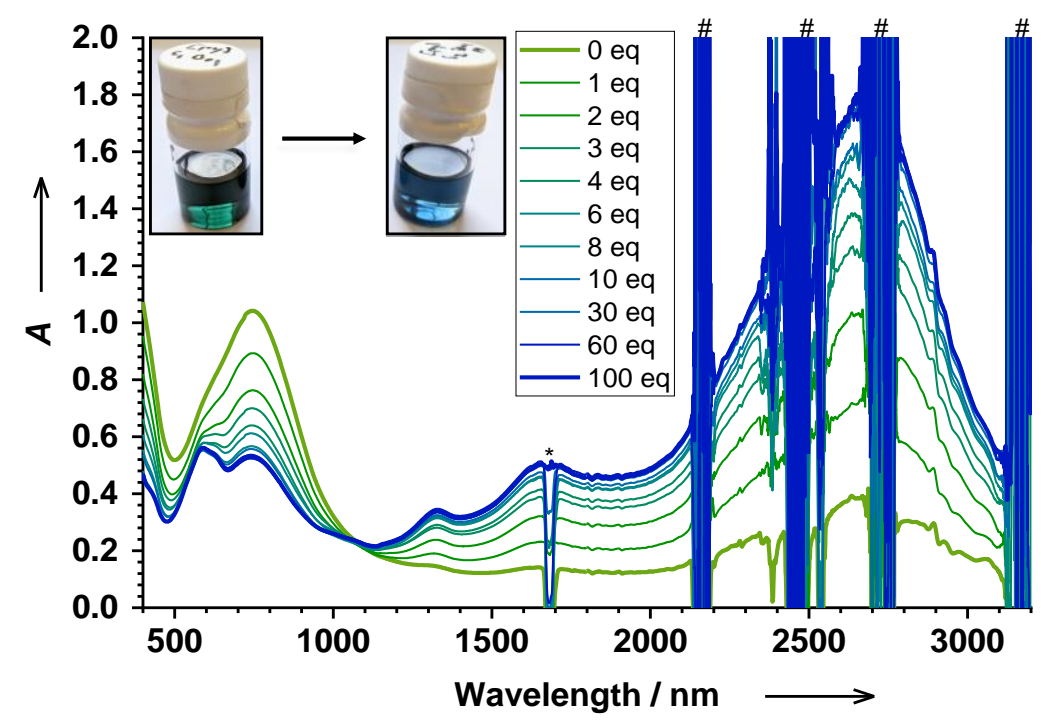

Figure S4: Electronic absorption spectrum of $\left[\mathbf{C o}\left({ }^{\mathrm{t}} \mathrm{Bu} \text {-dioxolene }\right)_{2}(\mathbf{p y})_{2}\right](2)$ in benzene $\left(c=5 \cdot 10^{-4} \mathrm{M}\right)$ with different amounts of excess pyridine. $(*)$ is a spectrometer artefact, $(\#)$ are due to solvent overtones.

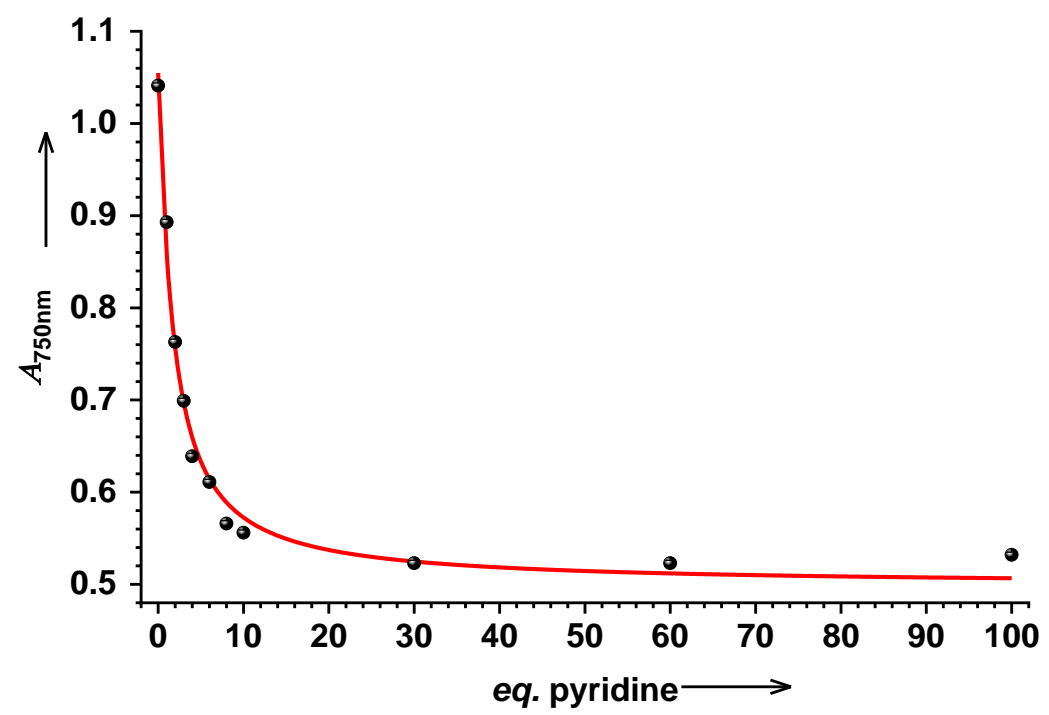

Figure S5: Evolution of the $750 \mathrm{~nm}$ absorption band of [Co('Bu-dioxolene $\left.)_{2}(\mathbf{p y})_{2}\right]$ (2) in benzene $\left(c=5 \cdot 10^{-4} \mathrm{M}\right)$ with different amounts of excess pyridine. Fit parameters: $\varepsilon_{\mathrm{A}}=2.9(1) \cdot 10^{3} \mathrm{M}^{-1} \mathrm{~cm}^{-1}, \quad \varepsilon_{\mathrm{B}}=1.00(2) \cdot 10^{3} \mathrm{M}^{-1} \mathrm{~cm}^{-1}$, $K_{a}=2.3(4) \cdot 10^{3} \mathrm{~L} \mathrm{~mol}^{-1}$. 


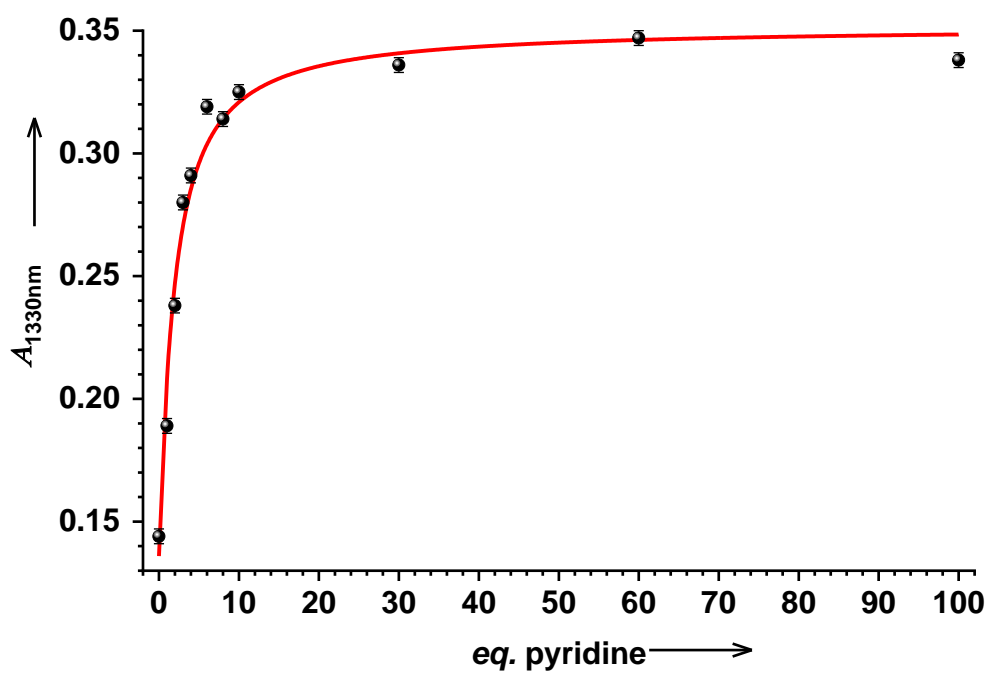

Figure S6: Evolution of the $1330 \mathrm{~nm}$ absorption band of $\left[\mathbf{C o}\left({ }^{(} \mathbf{B u}-\text { dioxolene }\right)_{2}(\mathbf{p y})_{2}\right](2)$ in benzene $\left(c=5 \cdot 10^{-4} \mathrm{M}\right)$ with different amounts of excess pyridine. Fit parameters: $\varepsilon_{\mathrm{A}}=0 \mathrm{M}^{-1} \mathrm{~cm}^{-1}, \quad \varepsilon_{\mathrm{B}}=0.70(1) \cdot 10^{3} \mathrm{M}^{-1} \mathrm{~cm}^{-1}$, $K_{a}=2.1(2) \cdot 10^{3} \mathrm{~L} \mathrm{~mol}^{-1}$.

\section{Titration with analyte}

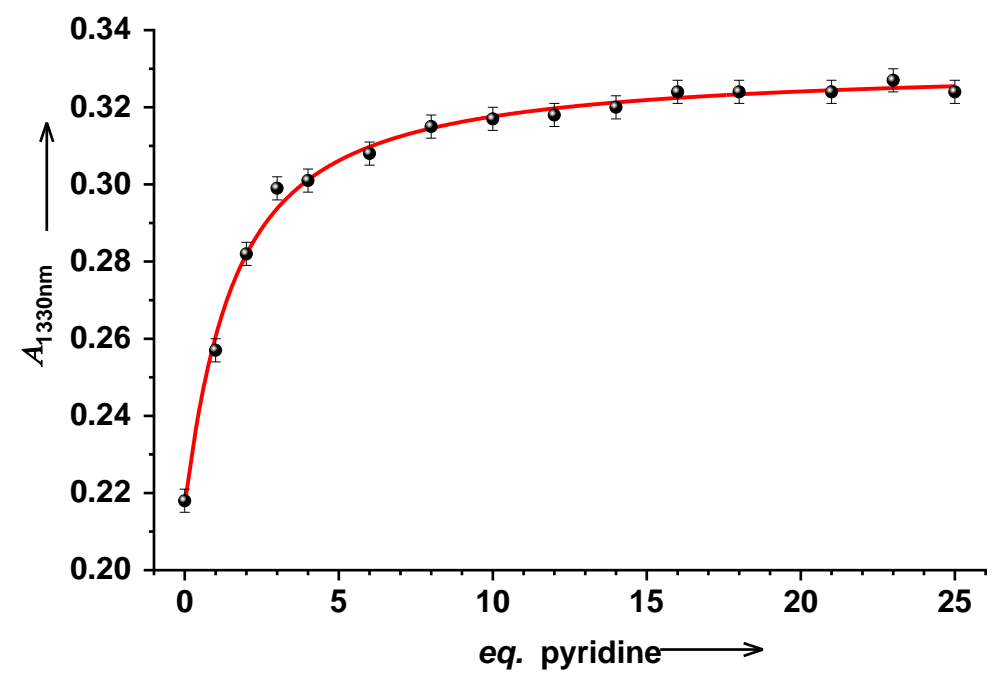

Figure S7: Evolution of the $1330 \mathrm{~nm}$ absorption band of [Co('Bu-dioxolene)2(stypy) 2 (1) in benzene $\left(c=5 \cdot 10^{-4} \mathrm{M}\right)$ with different amounts of excess pyridine. Fit parameters: $\varepsilon_{\mathrm{A}}=0.26(2) \cdot 10^{3} \mathrm{M}^{-1} \mathrm{~cm}^{-1}, \varepsilon_{\mathrm{B}}=0.662(2) \cdot 10^{3} \mathrm{M}^{-1} \mathrm{~cm}^{-1}$, $K_{a}=2.8(3) \cdot 10^{3} \mathrm{~L} \mathrm{~mol}^{-1}$. 


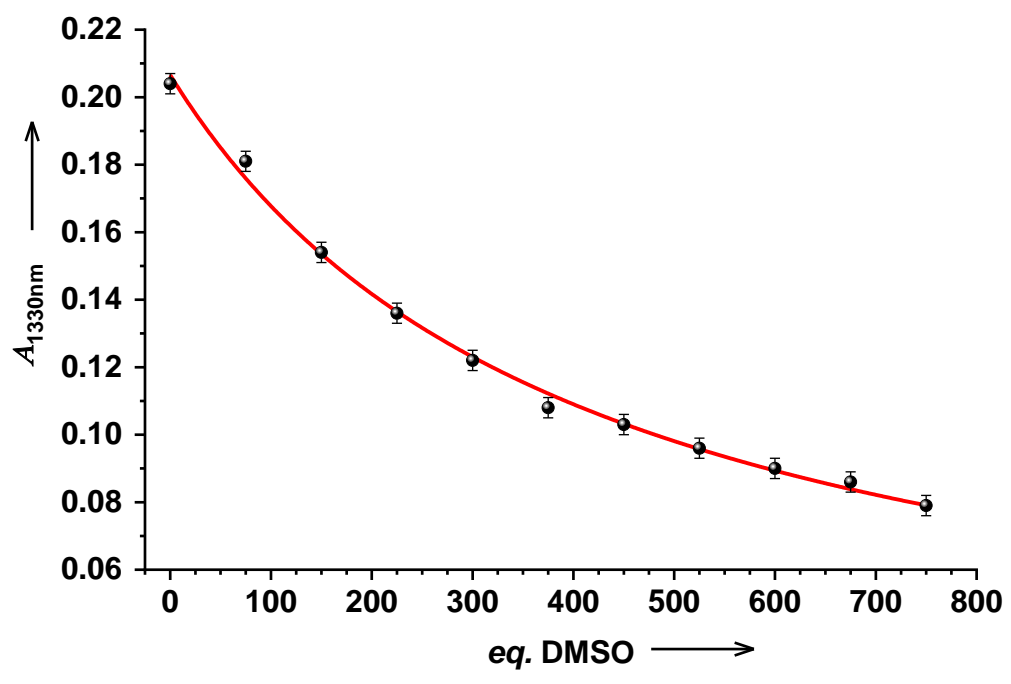

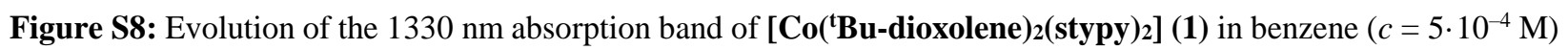
with different amounts of excess DMSO. Fit parameters: $\varepsilon_{\mathrm{A}}=0.414(5) \cdot 10^{3} \mathrm{M}^{-1} \mathrm{~cm}^{-1}, \varepsilon_{\mathrm{B}}=0.02(1) \cdot 10^{3} \mathrm{M}^{-1} \mathrm{~cm}^{-1}$, $K_{a}=5(1) \cdot 10^{3} \mathrm{~L} \mathrm{~mol}^{-1}$.

\section{Comparison of titration end points}

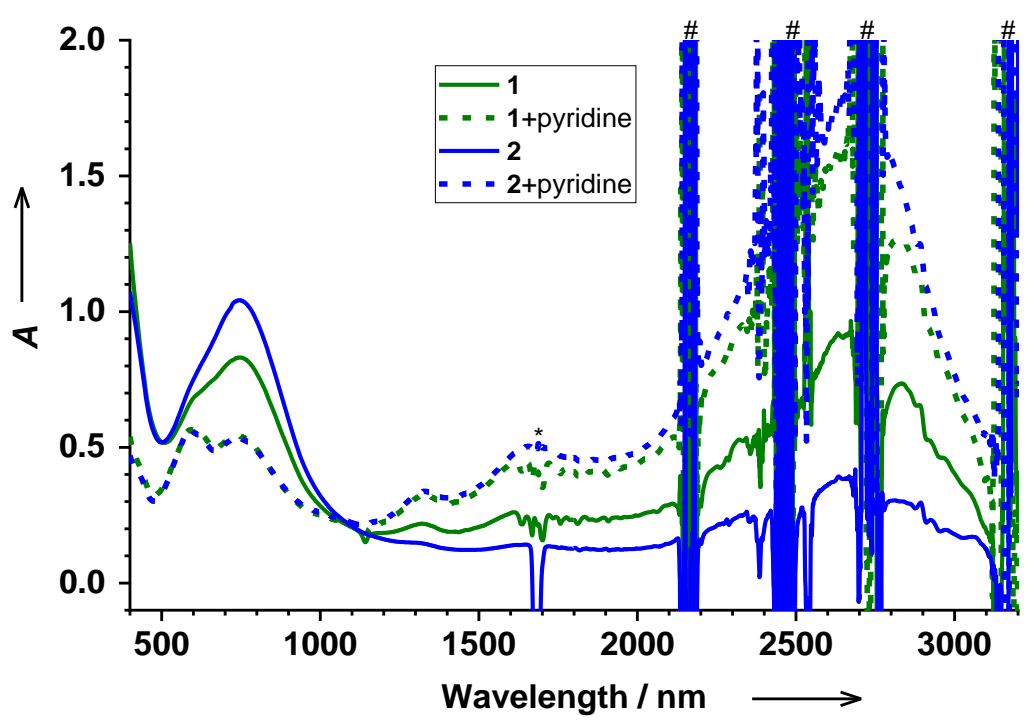

Figure S9: Comparison of electronic absorption spectra of [Co('Bu-dioxolene) $)_{2}\left(\right.$ stypy $\left._{2}\right]$ (1) (solid green) and [Co( ${ }^{\mathrm{t}} \mathrm{Bu}$-dioxolene) $\left.)_{2}(\mathbf{p y})_{2}\right]$ (2) (solid blue) in benzene $\left(c=5 \cdot 10^{-4} \mathrm{M}\right)$ and with excess pyridine (dashed green/blue). $(*)$ is a spectrometer artefact, (\#) are due to solvent overtones. 


\section{Magnetic response to analytes}

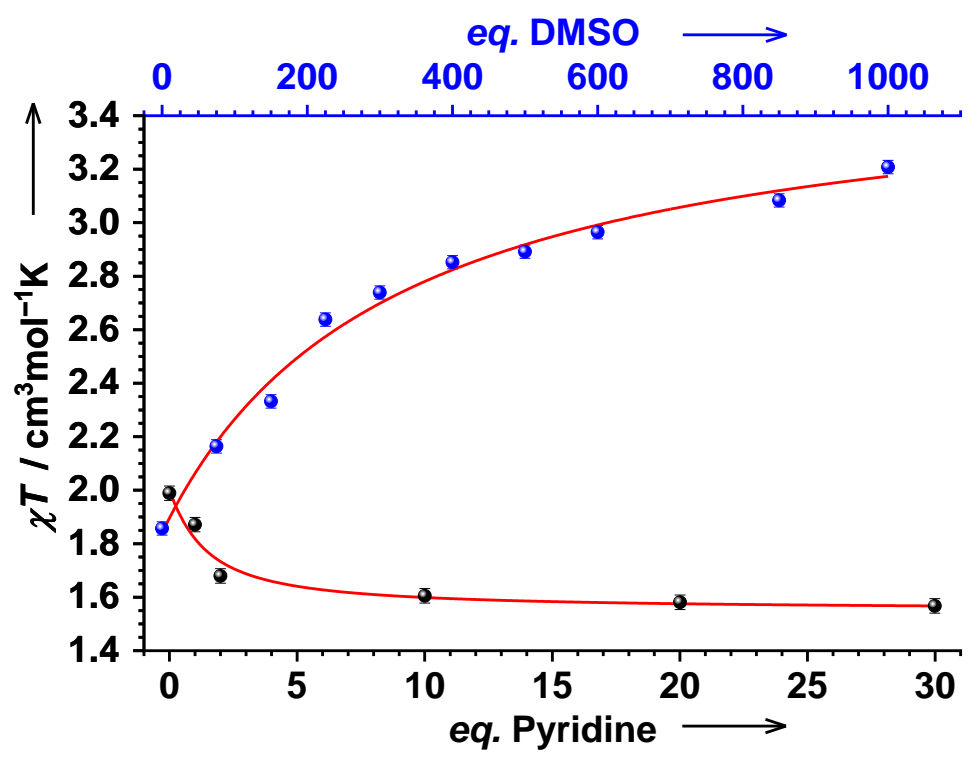

Figure S10: Changes of the $\chi T$ product of [Co( $\left.\left.{ }^{\text {(Bu-dioxolene) }}\right)_{2}(\text { stypy })_{2}\right]$ (1) in benzene:benzene- $d_{6}$ :TMS (10:2:1) $\left(c=5 \cdot 10^{-4} \mathrm{M}\right.$ ) with different amounts of pyridine (black) and DMSO (blue).

\section{Comparison of fitted parameters}

Table S1: Comparison of fit parameters $K_{a}, \varepsilon_{\mathrm{A}}$ and $\varepsilon_{\mathrm{B}}$ at $\lambda=750 \mathrm{~nm}$ determined by fitting data obtained from spectrophotometric titration experiments for [Co( ${ }^{(}{ }^{B}$ u-dioxolene $\left.)_{2}(\text { stypy })_{2}\right](1)$ and $\left[\mathrm{Co}\left({ }^{\mathrm{t} B u} \text {-dioxolene }\right)_{2}(\mathbf{p y})_{2}\right](2)$.

\begin{tabular}{|c|c|c|c|c|}
\hline Complex & Substrate & $\begin{array}{l}\boldsymbol{K}_{a}{ }^{a} \\
{\left[\mathrm{~L} \mathrm{~mol}^{-1}\right]}\end{array}$ & $\begin{array}{c}\boldsymbol{\varepsilon \mathbf { A } ^ { b }} \\
{\left[\mathrm{M}^{-1} \mathrm{~cm}^{-1}\right]}\end{array}$ & $\begin{array}{c}\boldsymbol{\varepsilon} \mathbf{B}^{c} \\
{\left[\mathrm{M}^{-1} \mathrm{~cm}^{-1}\right]}\end{array}$ \\
\hline \multirow{2}{*}{$\begin{array}{l}{\left[\mathrm{Co}\left({ }^{\mathrm{t}} \mathrm{Bu} \text {-dioxolene }\right)_{2}(\text { stypy })_{2}\right](\mathbf{1})} \\
{\left[\mathrm{Co}\left({ }^{\mathrm{t}} \mathrm{Bu} \text {-dioxolene }\right)_{2}(\mathrm{py})_{2}\right](\mathbf{2})}\end{array}$} & 4-styrylpyridine & $5.7(5) \cdot 10^{3}$ & $2.52(6) \cdot 10^{3}$ & $0.870(7) \cdot 10^{3}$ \\
\hline & pyridine & $2.3(4) \cdot 10^{3}$ & $2.9(1) \cdot 10^{3}$ & $1.00(2) \cdot 10^{3}$ \\
\hline$\left[\mathrm{Co}\left({ }^{(} \mathrm{Bu}-\text { dioxolene }\right)_{2}(\text { stypy })_{2}\right](\mathbf{1})$ & pyridine & $2.6(2) \cdot 10^{3 d}$ & $2.12(4) \cdot 10^{3}$ & $1.068(5) \cdot 10^{3}$ \\
\hline$\left[\mathrm{Co}\left({ }^{(\mathrm{Bu}} \text {-dioxolene }\right)_{2}(\text { stypy })_{2}\right](\mathbf{1})$ & DMSO & $1.9(5)^{d}$ & $1.60(1) \cdot 10^{3}$ & $2.7(2) \cdot 10^{3}$ \\
\hline
\end{tabular}

${ }^{a}$ association constant

${ }^{b}$ extinction coefficient of species A

${ }^{c}$ extinction coefficient of species B

${ }^{d}$ effective association constant

Table S2: Comparison of fit parameters $K_{a}, \varepsilon_{\mathrm{A}}$ and $\varepsilon_{\mathrm{B}}$ determined by fitting data at different wavelengths $(\lambda=750$ $\mathrm{nm}$ and $\lambda=1330 \mathrm{~nm}$ ) obtained from spectrophotometric titration experiments for [Co('Bu-dioxolene)2(stypy)2] (1) and [Co( ${ }^{\mathrm{t} B u}$-dioxolene $\left.)_{2}(\mathrm{py})_{2}\right](\mathbf{2})$. 


\begin{tabular}{|c|c|c|c|c|}
\hline Experiment & $\begin{array}{c}\lambda \\
{[\mathrm{nm}]}\end{array}$ & $\begin{array}{c}\boldsymbol{K}_{\boldsymbol{a}}{ }^{a} \\
{\left[\mathrm{~L} \mathrm{~mol}^{-1}\right]}\end{array}$ & $\begin{array}{c}\boldsymbol{\varepsilon}^{b} \\
{\left[\mathrm{M}^{-1} \mathrm{~cm}^{-1}\right]}\end{array}$ & $\begin{array}{c}\boldsymbol{E}^{c}{ }^{c} \\
{\left[\mathrm{M}^{-1} \mathrm{~cm}^{-1}\right]}\end{array}$ \\
\hline \multirow{2}{*}{$\begin{array}{c}{\left[\mathrm{Co}\left(\mathrm{C}^{\mathrm{B} u} \text {-dioxolene }\right)_{2}(\text { stypy })_{2}\right](\mathbf{1})} \\
+ \\
\text { 4-styrylpyridine }\end{array}$} & 750 & $5.7(5) \cdot 10^{3}$ & $2.52(6) \cdot 10^{3}$ & $0.870(7) \cdot 10^{3}$ \\
\hline & 1330 & $5.0(1) \cdot 10^{3}$ & 0 & $0.708(2) \cdot 10^{3}$ \\
\hline \multirow{2}{*}{$\begin{array}{c}{\left[\mathrm{Co}\left({ }^{\mathrm{t}} \mathrm{Bu}-\text { dioxolene }\right)_{2}(\mathrm{py})_{2}\right](\mathbf{2})} \\
+ \\
\text { pyridine }\end{array}$} & 750 & $2.3(4) \cdot 10^{3}$ & $2.9(1) \cdot 10^{3}$ & $1.00(2) \cdot 10^{3}$ \\
\hline & 1330 & $2.1(2) \cdot 10^{3}$ & 0 & $0.70(1) \cdot 10^{3}$ \\
\hline \multirow{2}{*}{$\begin{array}{c}{\left[\mathrm{Co}\left({ }^{\mathrm{t}} \mathrm{Bu}-\text { dioxolene }\right)_{2}(\text { stypy })_{2}\right](\mathbf{1})} \\
+ \\
\text { pyridine }\end{array}$} & 750 & $2.6(2) \cdot 10^{3 d}$ & $2.12(4) \cdot 10^{3}$ & $1.068(5) \cdot 10^{3}$ \\
\hline & 1330 & $2.8(3) \cdot 10^{3 d}$ & $0.26(2) \cdot 10^{3}$ & $0.662(2) \cdot 10^{3}$ \\
\hline \multirow{2}{*}{$\begin{array}{c}{\left[\mathrm{Co}(\text { Bu-dioxolene })_{2}(\text { stypy })_{2}\right](\mathbf{1})} \\
+ \\
\text { DMSO }\end{array}$} & 750 & $1.9(5)^{d}$ & $1.60(1) \cdot 10^{3}$ & $2.7(2) \cdot 10^{3}$ \\
\hline & 1330 & $5(1)^{d}$ & $0.414(5) \cdot 10^{3}$ & $0.02(1) \cdot 10^{3}$ \\
\hline
\end{tabular}

${ }^{a}$ association constant

${ }^{b}$ extinction coefficient of species A

${ }^{c}$ extinction coefficient of species B

${ }^{d}$ effective association constant 
Table S3: Comparison of fit parameters $K_{a}, \chi_{\mathrm{A}} T$ and $\chi_{\mathrm{B}} T$ determined by fitting data from titration experiments followed with Evans NMR method for [Co('Bu-dioxolene)2(stypy)2] (1).

\begin{tabular}{|c|cccc|}
\multicolumn{1}{c}{$\begin{array}{c}\text { Complex } \\
\text { Evans NMR }\end{array}$} & Substrate & $\begin{array}{c}\boldsymbol{K}_{\mathbf{a}}{ }^{a} \\
{\left[\mathrm{~L} \mathrm{~mol}^{-1}\right]}\end{array}$ & $\begin{array}{c}\chi_{\mathbf{A}} \boldsymbol{T}^{b} \\
{\left[\mathrm{~cm}^{3} \mathrm{~mol}^{-1} \mathrm{~K}\right]}\end{array}$ & $\begin{array}{c}\chi_{\mathbf{B}} \boldsymbol{T}^{c} \\
{\left[\mathrm{~cm}^{3} \mathrm{~mol}^{-1} \mathrm{~K}\right]}\end{array}$ \\
\hline $\begin{array}{c}{\left[\mathrm{Co}\left({ }^{\mathrm{B}} \mathrm{Bu} \text {-dioxolene }\right)_{2}(\text { stypy })_{2}\right](\mathbf{1})} \\
{\left[\mathrm{Co}\left({ }^{\mathrm{B} B u} \text {-dioxolene }\right)_{2}(\text { stypy })_{2}\right](\mathbf{1})}\end{array}$ & pyridine & $3(2) \cdot 10^{3}$ & $2.4(2)$ & $1.54(3)$ \\
\hline${ }^{a}$ effective association constant & DMSO & $6(1)$ & $1.84(5)$ & $3.6(1)$ \\
${ }^{b} \chi T$ product of pseudo-species A & & & \\
${ }^{c} \chi T$ product of pseudo-species B & & & \\
\hline
\end{tabular}




\section{Mass Spectrometry}

The signals in green originate from the solution with $10^{4}$ equivalents of DMSO. The signals in red originate from the solution with $10^{4}$ equivalents of DMSO- $d_{6}$. The signals in grey represent the simulated isotope pattern. The water in these complexes originates from the mass spectrometer and not from the solution. These complexes are generated from other complexes by first losing one ligand followed by taking up residual water impurities from the collision cell. The water uptake by metal-containing ions is a common phenomenon in these experiments. 


\section{Isotope pattern (positive-ion ESI-MS)}
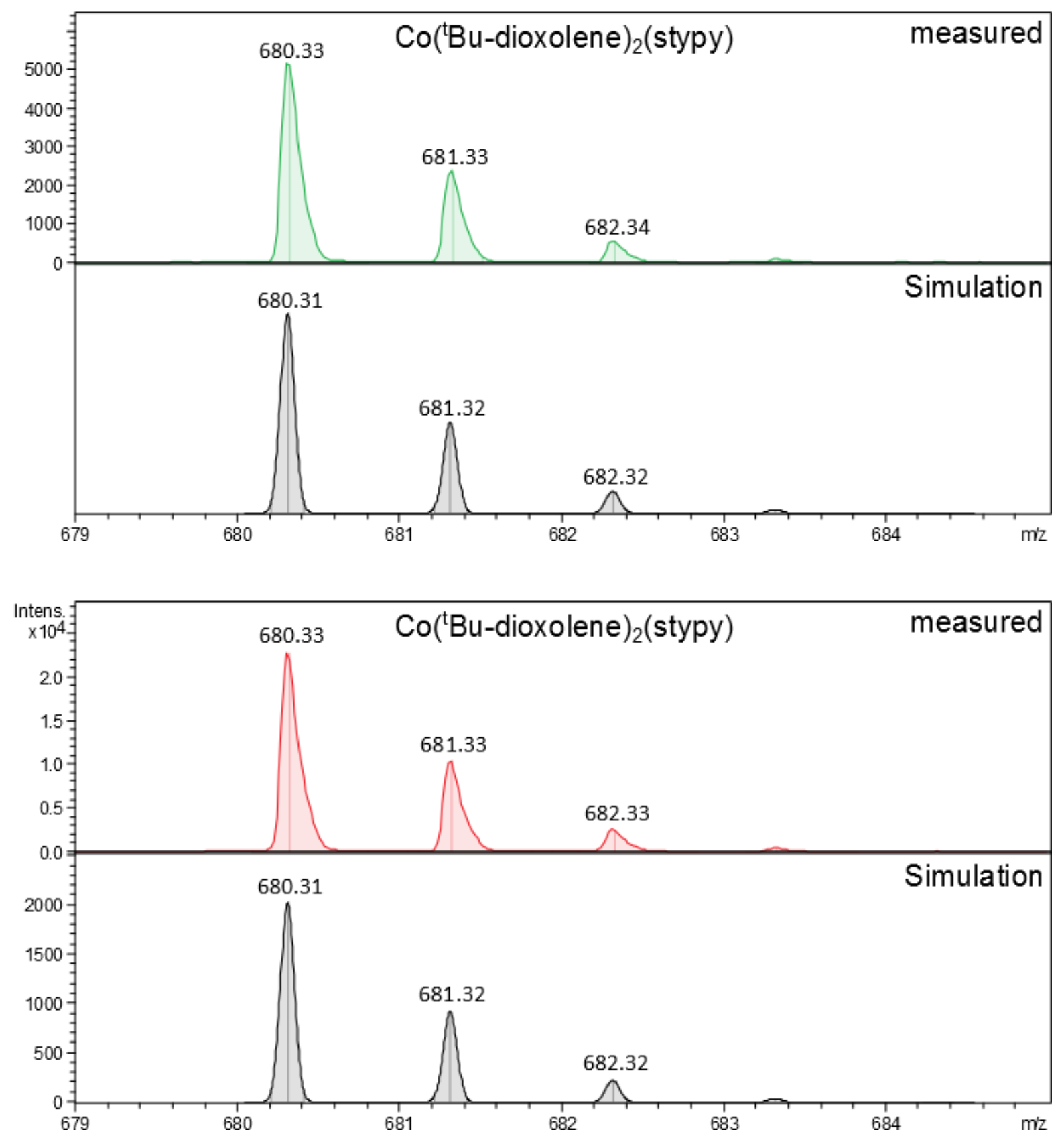

Figure S11: Isotope pattern of the signal at $680.31 \mathrm{~m} / \mathrm{z}\left(\left[\mathbf{C o}\left({ }^{(} \mathbf{B u}-\text { dioxolene }\right)_{2}(\mathbf{s t y p y})\right]^{+}\right)$for a solution of $\mathbf{1}$ in DCM with $10^{4}$ equivalents of DMSO (green, top) and DMSO-d (red, bottom) with simulation (grey). 

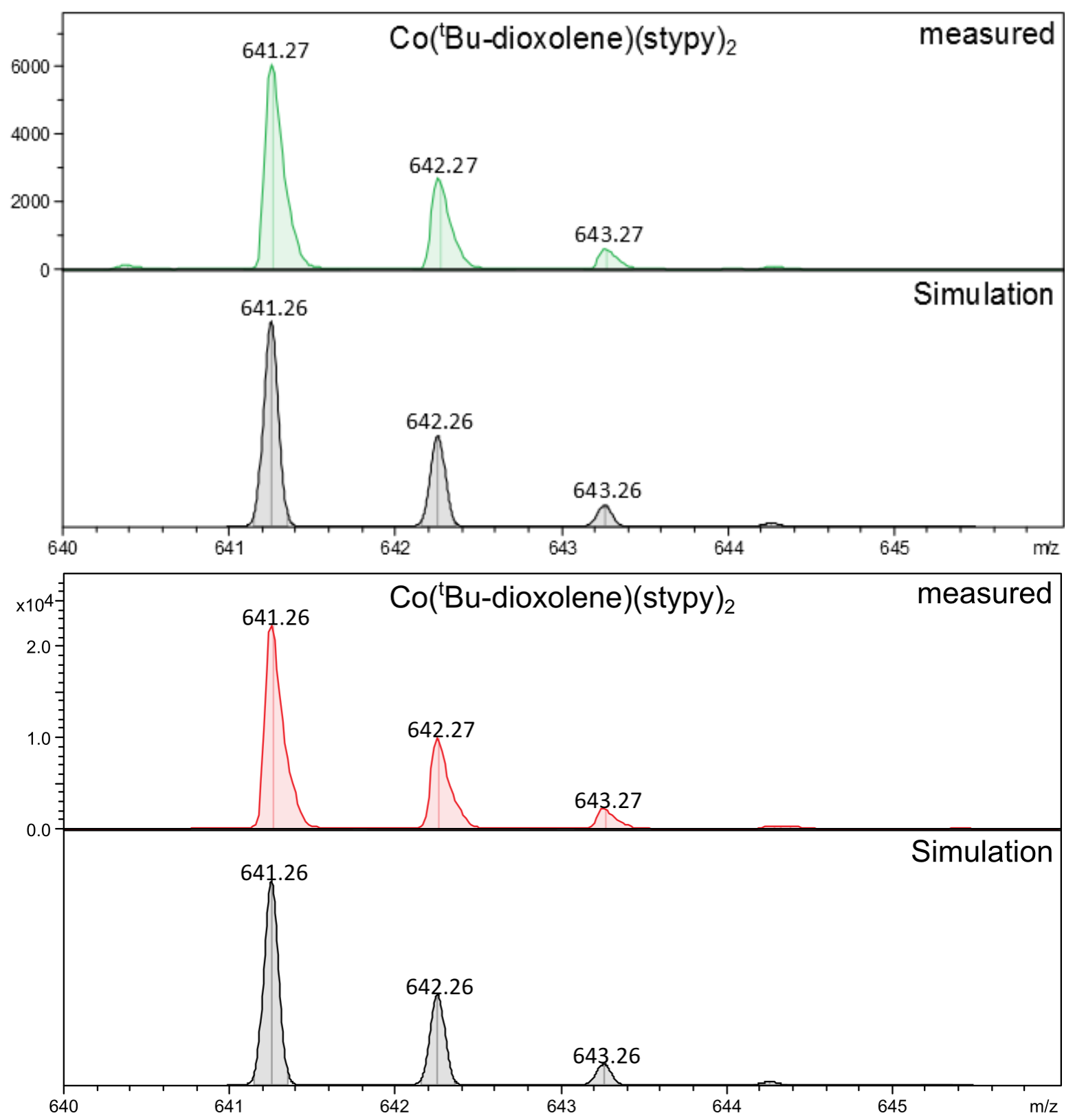

Figure S12: Isotope pattern of the signal at $641.26 \mathrm{~m} / \mathrm{z}\left(\left[\mathbf{C o}\left({ }^{+} \text {Bu-dioxolene)(stypy) }\right]_{2}\right]^{+}\right)$for a solution of $\mathbf{1}$ in DCM with $10^{4}$ equivalents of DMSO (green, top) and DMSO-d 6 (red, bottom) with simulation (grey). 

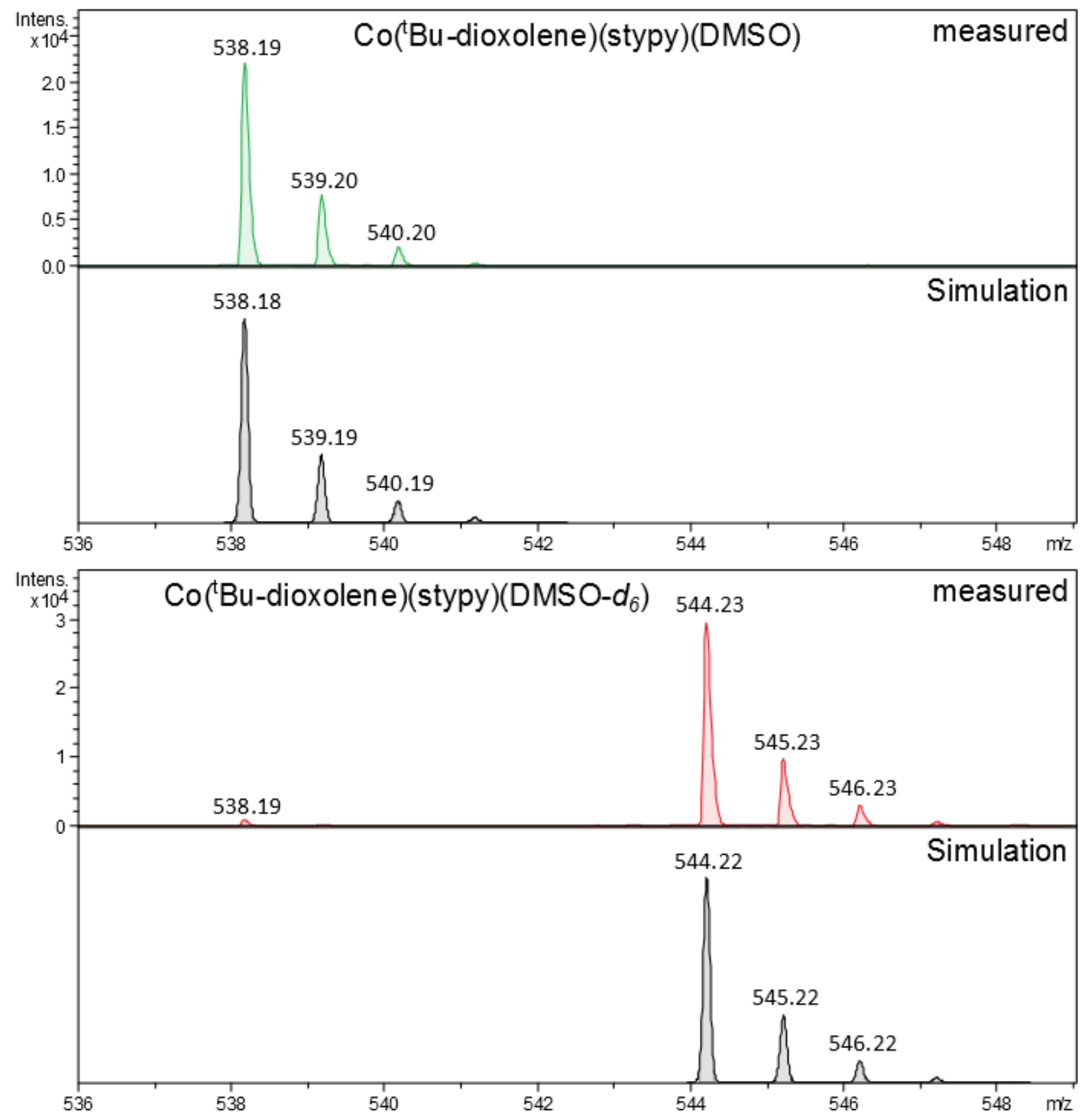

Figure S13: Isotope pattern of the signal at $538.26 \mathrm{~m} / \mathrm{z}$ ([Co('Bu-dioxolene)(stypy)(DMSO) $]^{+}$) for a solution of $\mathbf{1}$ in DCM with $10^{4}$ equivalents of DMSO (green, top) and isotope pattern of the signal at $544.22 \mathrm{~m} / \mathrm{z}$ ([Co( ${ }^{\mathrm{t}} \mathrm{Bu}-$ dioxolene)(stypy)(DMSO- $\left.d_{6}\right)$ ]) for a solution of 1 with $10^{4}$ equivalents of DMSO-d $\boldsymbol{d}_{\boldsymbol{6}}$ (red, bottom) with simulation (grey) showing the expected mass shift of 6 mass units. 


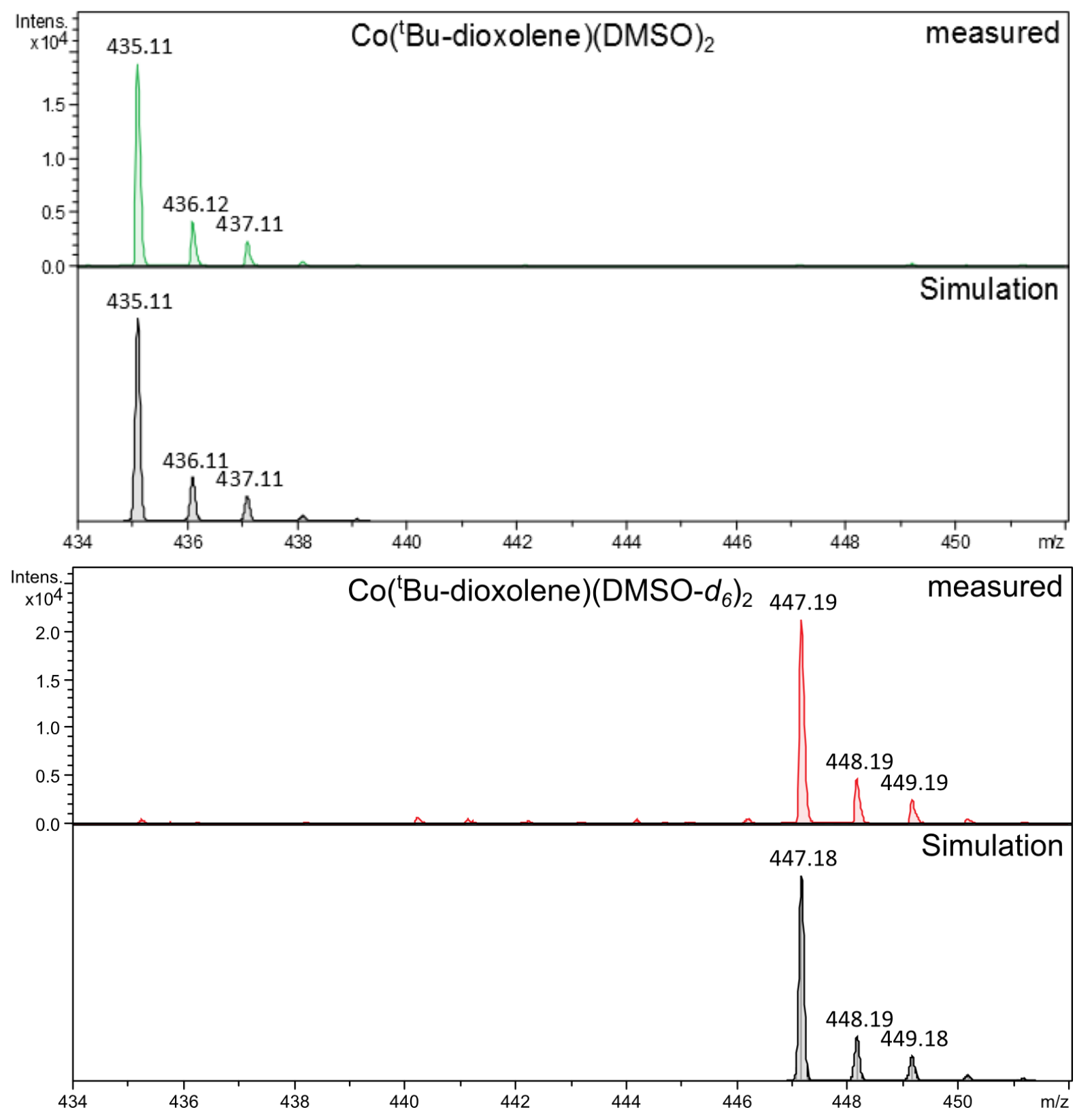

Figure S14: Isotope pattern of the signal at $435.11 \mathrm{~m} / \mathrm{z}\left(\left[\mathbf{C o}\left({ }^{\mathrm{t} B u} \text {-dioxolene)(DMSO) }\right)^{+}\right)\right.$for a solution of $\mathbf{1}$ in DCM with $10^{4}$ equivalents of DMSO (green, top) and isotope pattern of the signal at $447.19 \mathrm{~m} / \mathrm{z}$ ([Co( ${ }^{\mathrm{t}} \mathrm{Bu}-$ dioxolene)(stypy)(DMSO- $\left.\left.d_{6}\right)_{2}\right]$ ) for a solution of $\mathbf{1}$ with $10^{4}$ equivalents of DMSO-d (red, bottom) with simulation (grey) showing the expected mass shift of 12 mass units. 

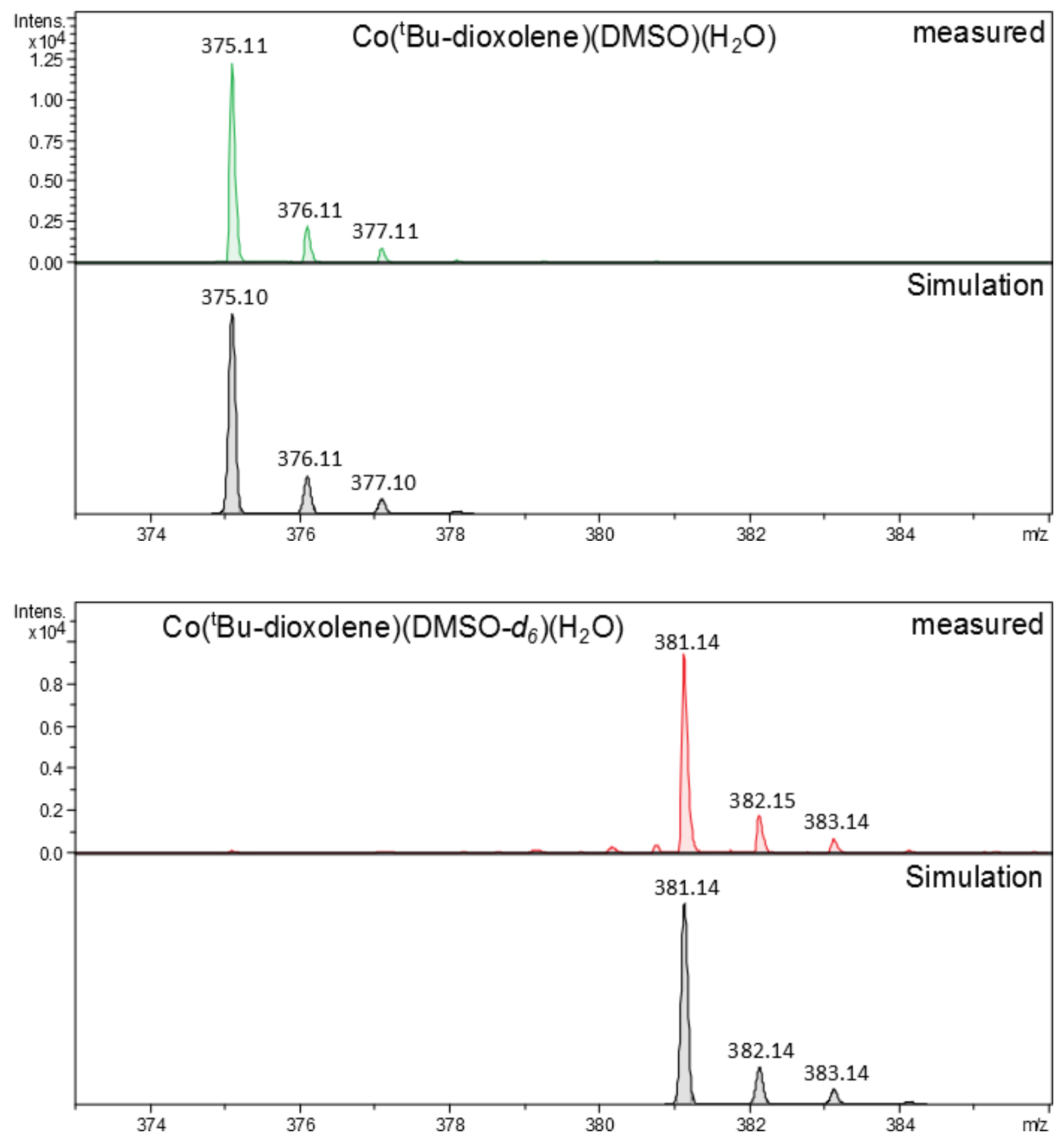

Figure S15: Isotope pattern of the signal at $375.11 \mathrm{~m} / \mathrm{z}\left(\left[\mathbf{C o}\left({ }^{\mathrm{t}} \mathbf{B u}-\text { dioxolene)(DMSO)( } \mathbf{H}_{2} \mathbf{O}\right)\right]^{+}\right)$for a solution of $\mathbf{1}$ in DCM with $10^{4}$ equivalents of DMSO (green, top) and isotope pattern of the signal at $381.14 \mathrm{~m} / \mathrm{z}$ ([Co( ${ }^{\mathrm{t}} \mathrm{Bu}-$ dioxolene)(stypy)(DMSO- $\left.\left.d_{6}\right)\left(\mathrm{H}_{2} \mathrm{O}\right)\right]$ ) for a solution of 1 with $10^{4}$ equivalents of DMSO-d (red, bottom) with simulation (grey) showing the expected mass shift of 6 mass units. 


\section{MS/MS spectra}

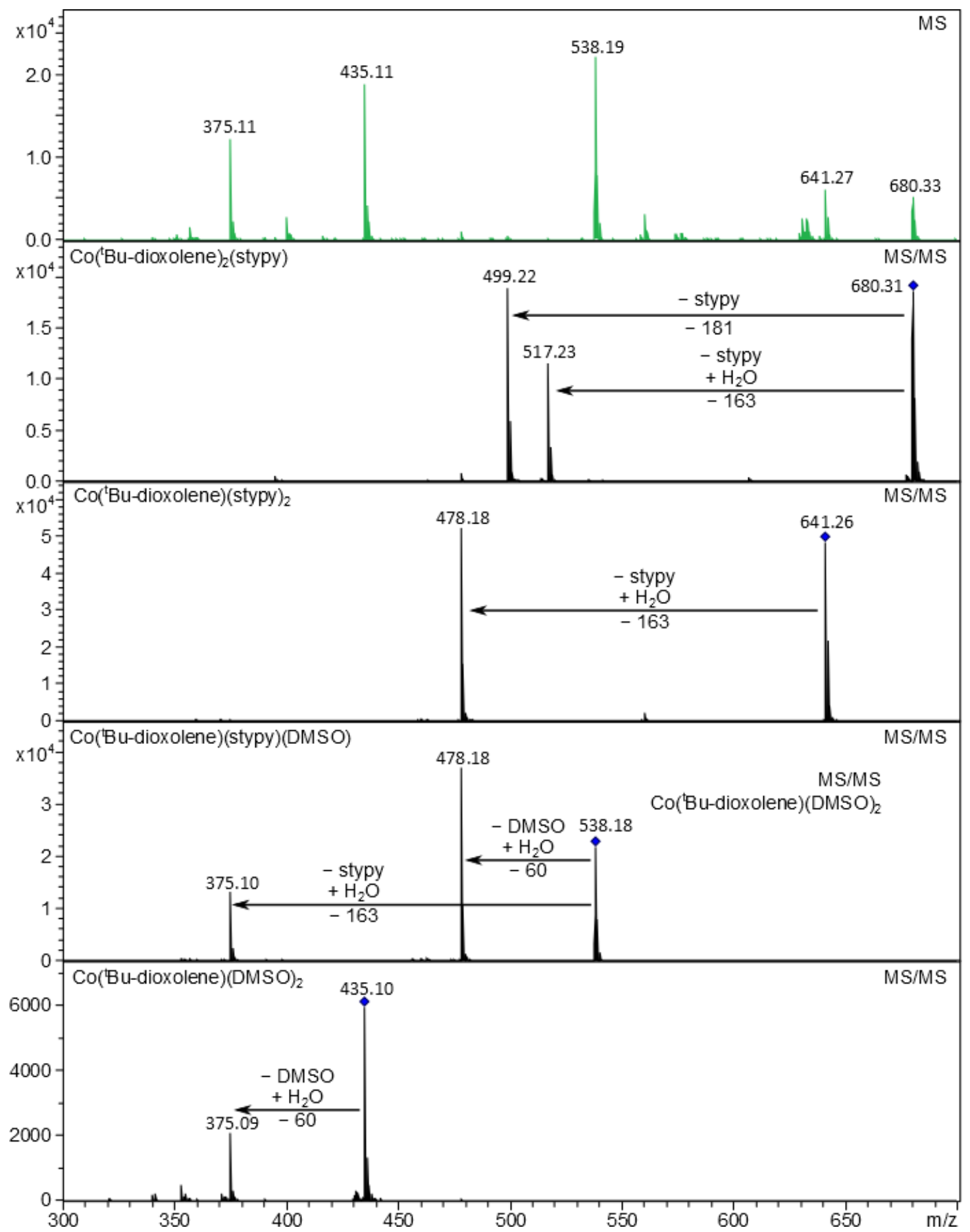

Figure S16: Mass spectrum of a solution of [Co('Bu-dioxolene) $\left.)_{2}(\text { stypy })_{2}\right]$ (1) in DCM with $10^{4}$ equivalents of DMSO (top, green) and MS/MS (CID) spectra of selected precursor ions (black). 


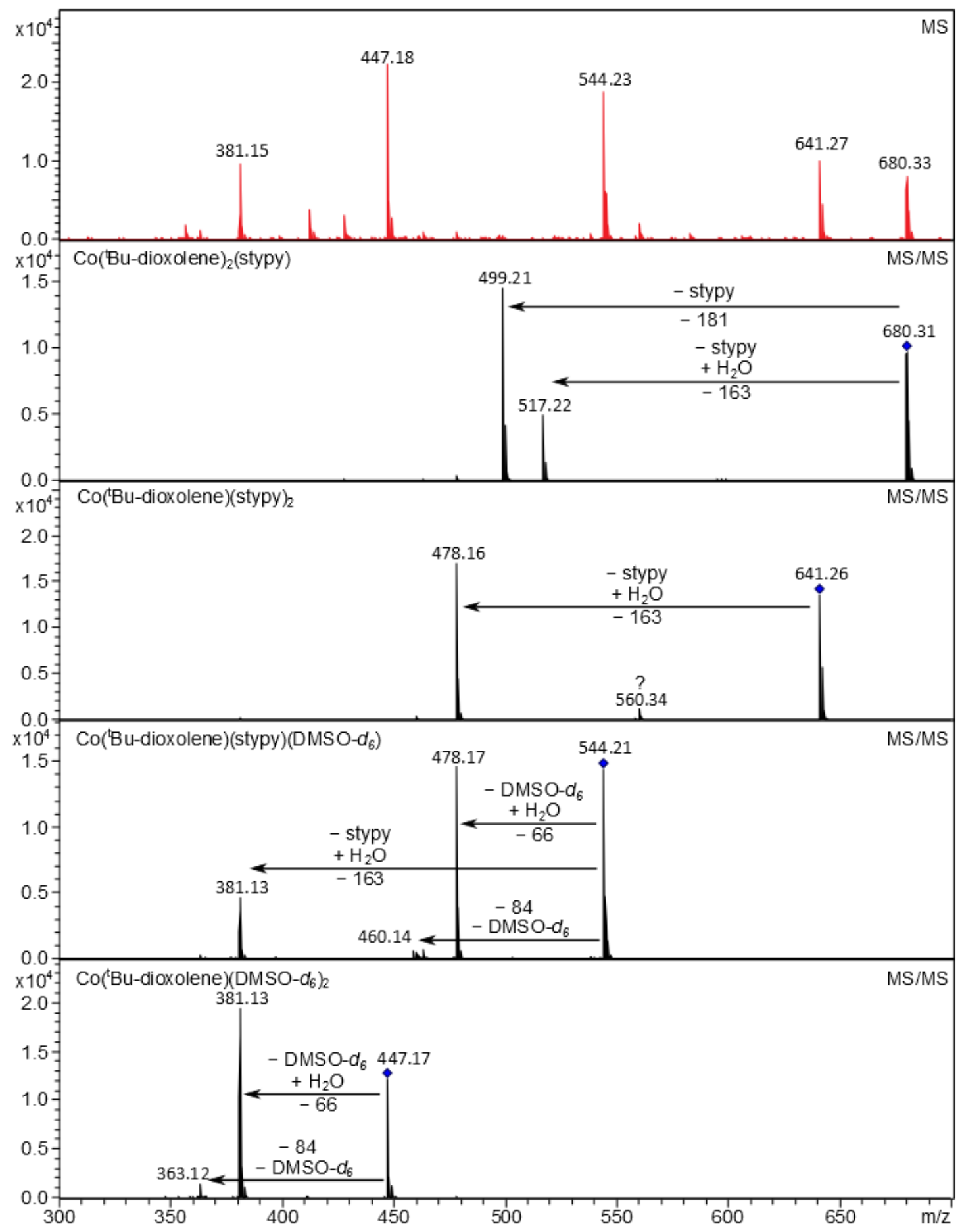

Figure S17: Mass spectrum of a solution of $\left[\mathbf{C o}\left({ }^{t} \mathbf{B u}-\text {-dioxolene }\right)_{2}(\mathbf{s t y p y})_{2}\right](\mathbf{1})$ in DCM with $10^{4}$ equivalents of DMSO-d $\boldsymbol{d}_{\boldsymbol{\sigma}}$ (top, red) and MS/MS (CID) spectra of selected precursor ions. 


\section{Cyclic Voltammetry}

The reference complex $\left[\mathrm{Co}\left({ }^{\mathrm{t}} \mathrm{Bu}-\text { dioxolene }\right)_{2}(\mathrm{py})_{2}\right](2)$ has been electrochemically characterized. Its redox properties have been compared with that of $\left[\mathrm{Co}\left({ }^{\mathrm{t}} \mathrm{Bu} \text {-dioxolene }\right)_{2}(\text { stypy })_{2}\right](\mathbf{1})$, remeasured $^{1}$ in this work.

\section{Reference complex}

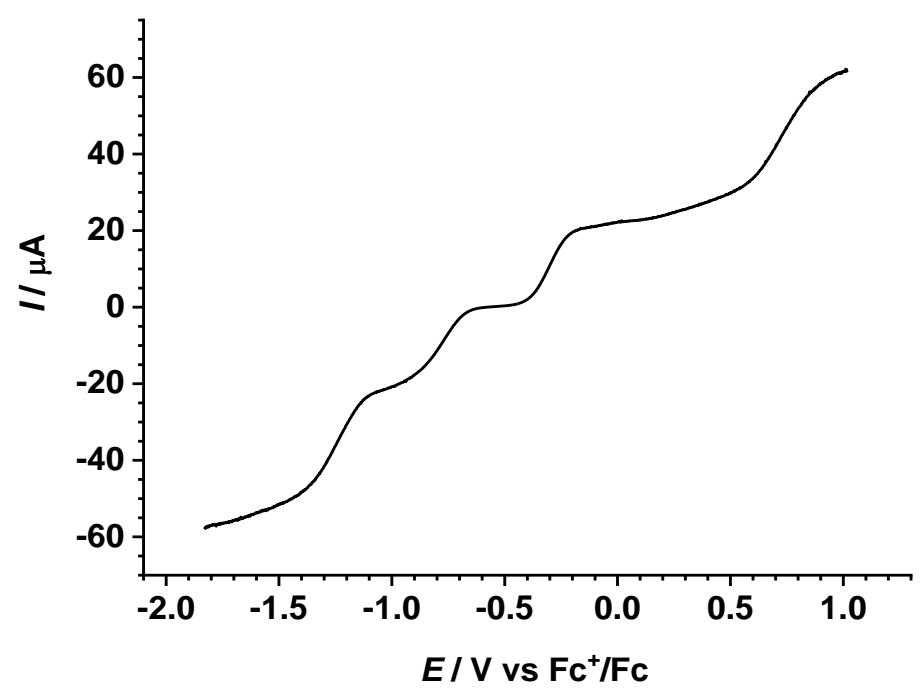

Figure S18: Linear sweep of $\left[\mathrm{Co}\left({ }^{\mathrm{t}} \mathrm{Bu}-\text { dioxolene }\right)_{2}(\mathbf{p y})_{2}\right](2)$ in $\mathrm{DCM}\left(c=5 \cdot 10^{-4} \mathrm{M}\right)$ at RT containing ${ }^{n} \mathrm{Bu}_{4} \mathrm{NPF}_{6}(0.1$ M) as supporting electrolyte. 


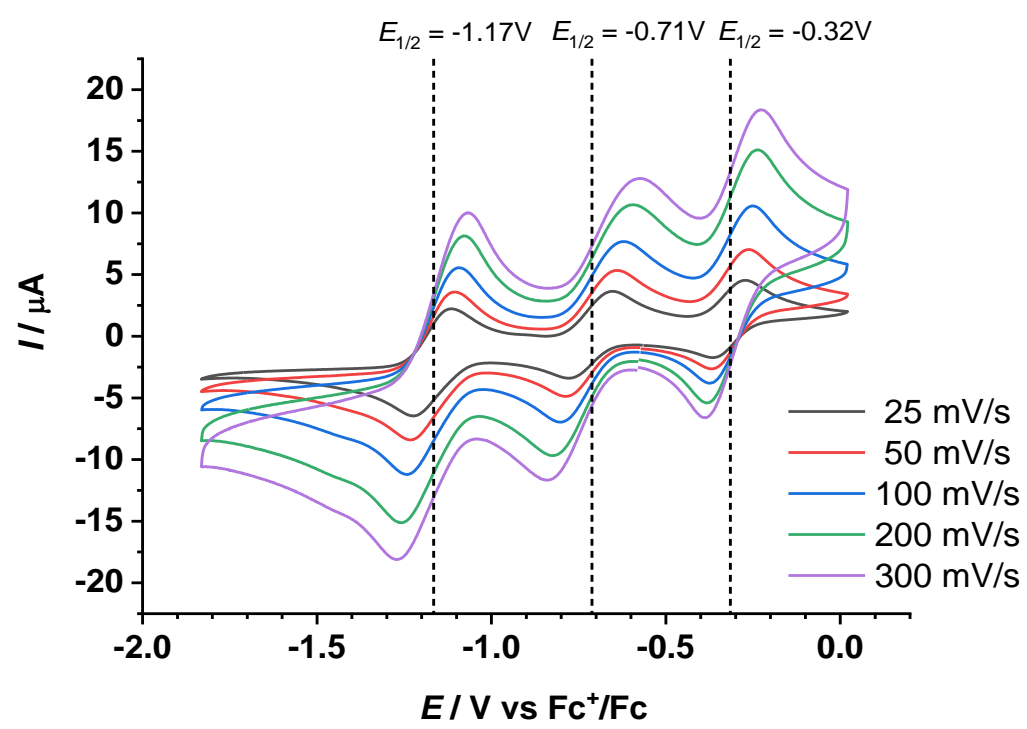

Figure S19: Small range cyclic voltammogram of [Co( ${ }^{\mathrm{t}} \mathrm{Bu}$-dioxolene $\left.)_{2}(\mathbf{p y})_{2}\right](\mathbf{2})$ in $\mathrm{DCM}\left(c=5 \cdot 10^{-4} \mathrm{M}\right)$ containing ${ }^{n} \mathrm{Bu}_{4} \mathrm{NPF}_{6}(0.1 \mathrm{M})$ as supporting electrolyte, measured at $\mathrm{RT}$ and at different scan rates $(0.025-0.3 \mathrm{~V} / \mathrm{s})$.

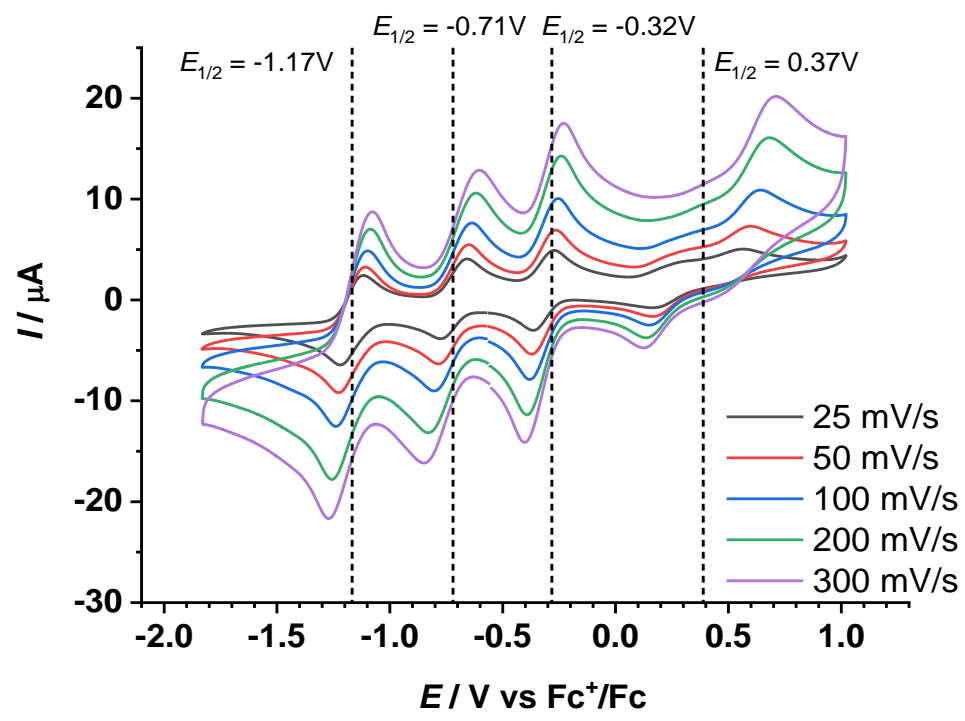

Figure S20: Full range cyclic voltammogram of [Co( $\left.\left.{ }^{(} \mathbf{B u}-d i o x o l e n e\right) 2(\mathbf{p y})_{2}\right](\mathbf{2})$ in DCM $\left(c=5 \cdot 10^{-4} \mathrm{M}\right)$ containing ${ }^{n} \mathrm{Bu}_{4} \mathrm{NPF}_{6}(0.1 \mathrm{M})$ as supporting electrolyte, measured at $\mathrm{RT}$ and at different scan rates $(0.025-0.3 \mathrm{~V} / \mathrm{s})$. 


\section{Comparison of cyclic voltammetry data}

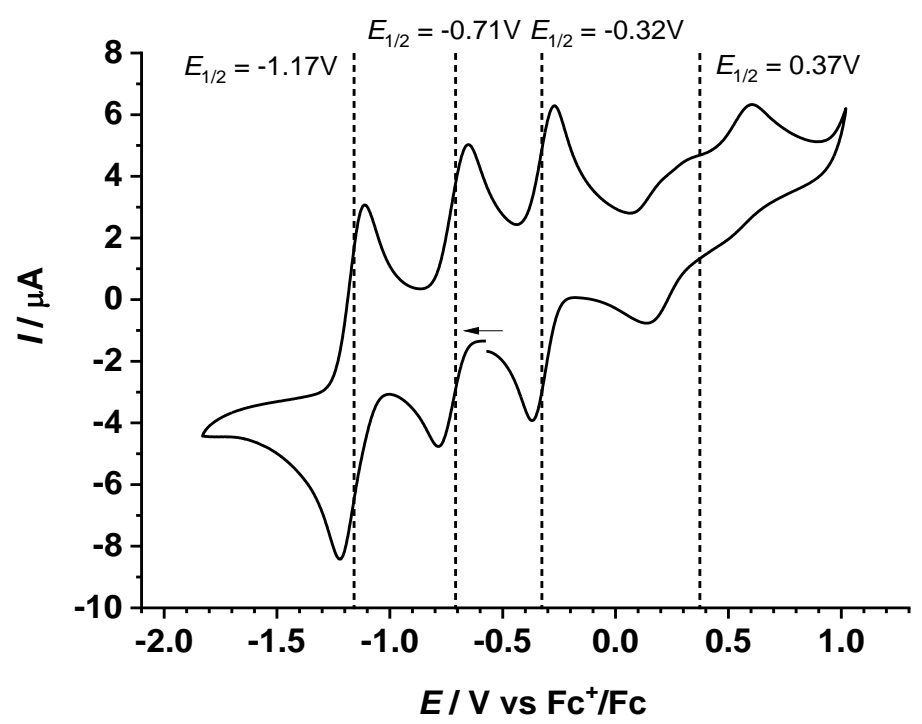

Figure S21: Full range cyclic voltammogram of $\left[\mathbf{C o}\left({ }^{\mathrm{t}} \mathbf{B u} \text {-dioxolene }\right)_{2}(\mathbf{p y})_{2}\right](\mathbf{2})$ in $\mathrm{DCM}\left(c=5 \cdot 10^{-4} \mathrm{M}\right)$, containing ${ }^{n} \mathrm{Bu}_{4} \mathrm{NPF}_{6}(0.1 \mathrm{M})$ as supporting electrolyte, measured at RT and at $0.025 \mathrm{~V} / \mathrm{s}$.

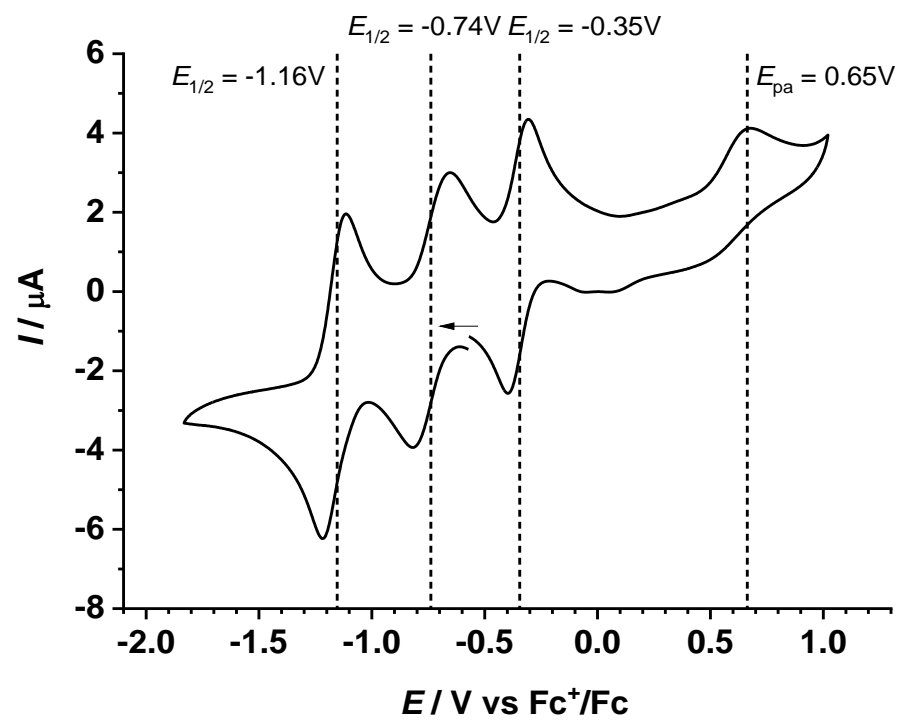

Figure S22: Full range cyclic voltammogram of [Co('Bu-dioxolene) 2 (stypy) $)_{2}$ (1) in DCM $\left(c=5 \cdot 10^{-4} \mathrm{M}\right)$, containing ${ }^{n} \mathrm{Bu}_{4} \mathrm{NPF}_{6}(0.1 \mathrm{M})$ as supporting electrolyte, measured at $\mathrm{RT}$ and at $0.025 \mathrm{~V} / \mathrm{s}$. 
Table S4: Cyclic voltammetry data for solutions of [Co( $\left.\left.{ }^{\mathrm{t} B u-d i o x o l e n e}\right)_{2}(\mathrm{py})_{2}\right](2)$ and [Co( $\left.\left.{ }^{(\mathrm{Bu}-d i o x o l e n e}\right)_{2}(\mathrm{stypy})_{2}\right]$ (1) in DCM $\left(c=5 \cdot 10^{-4} \mathrm{M}, 0.1 \mathrm{M}^{n} \mathrm{Bu}_{4} \mathrm{NPF}_{6}\right)$ at a scan rate of $0.025 \mathrm{~V} / \mathrm{s}$.

\begin{tabular}{|c|c|c|c|c|}
\hline & $\begin{array}{l}\boldsymbol{E}_{\mathbf{p c}} \\
{[\mathrm{V}]}\end{array}$ & $\begin{array}{l}\boldsymbol{E}_{\mathbf{p a}} \\
{[\mathrm{V}]}\end{array}$ & $\begin{array}{c}\left|\Delta \boldsymbol{E}_{\mathbf{p}}\right| \\
{[\mathrm{V}]}\end{array}$ & $\begin{array}{l}\boldsymbol{E}_{1 / 2} \\
{[\mathrm{~V}]}\end{array}$ \\
\hline & \multicolumn{4}{|c|}{$\left[\mathrm{Co}\left({ }^{\mathrm{t} B u} \text {-dioxolene }\right)_{2}(\mathrm{py})_{2}\right](2)$} \\
\hline$o x 2$ & 0.17 & 0.56 & 0.39 & 0.37 \\
\hline oxl & -0.36 & -0.27 & 0.09 & -0.32 \\
\hline redl & -0.77 & -0.65 & 0.12 & -0.71 \\
\hline \multirow[t]{2}{*}{ red2 } & -1.22 & -1.11 & 0.11 & -1.17 \\
\hline & \multicolumn{4}{|c|}{$\left[\mathrm{Co}\left({ }^{(} \mathrm{Bu}-\text { dioxolene }\right)_{2}(\text { stypy })_{2}\right](1)$} \\
\hline$o \times 2$ & $-^{a}$ & 0.65 & $-{ }^{a}$ & $-{ }^{a}$ \\
\hline$o x 1$ & -0.40 & -0.31 & 0.09 & -0.35 \\
\hline redl & -0.85 & -0.65 & 0.2 & -0.74 \\
\hline red2 & -1.21 & -1.11 & 0.1 & -1.16 \\
\hline
\end{tabular}

Cyclic voltammetry of $\mathbf{2}$ in DCM solution (see Figure S21) shows two reversible reductions (red1, red2), one reversible oxidation (oxl), and another less reversible oxidation (ox2). The cyclic voltammogram of $\mathbf{1}$ under similar conditions (see Figure S22) shows similar redox waves, with ox2 being even less reversible. These redox waves are characteristic for cobalt-dioxolene complexes with two axial $N$-donor ligands. ${ }^{1,4}$

Since complexes $\mathbf{1}$ and $\mathbf{2}$ exist in a valence tautomeric equilibrium between $h s-\mathrm{Co}^{\mathrm{II}}$ and $l s-\mathrm{Co}^{\mathrm{III}}$ redox isomers and since they are partially dissociated in solution, the assignment of observed redox waves to particular redox processes is difficult. Possible assignments for $\mathbf{2}$ are discussed below and summarized in Table S5, which includes the electrochemical data for $\mathbf{1}$ obtained for comparison. In all cases, there is ambiguity, whether it is a ligand-based or a metal-based redox process. Furthermore, the follow up rearrangement of electronic distribution is likely to occur due to close energy of ligand-based and metal-based redox orbitals in these complexes. 
Since $\mathrm{Co}(\mathrm{II}) \rightarrow \mathrm{Co}(\mathrm{I})$ reduction is unlikely at examined negative potentials,,${ }^{5-7}$ two-electron reduced species are likely $\mathrm{Co}(\mathrm{II})$ complexes with two fully reduced dioxolene ligands $\left(\mathrm{Cat}^{2-}\right)$ as in $\left[\mathrm{Co}^{\mathrm{II}}\left(\mathrm{Cat}^{2-}\right)\left(\mathrm{Cat}^{2-}\right)\right]^{2-}$, regardless of the nature of the parent one-electron reduced species. Both red 2 at $E_{1 / 2}=-1.17 \mathrm{~V}$ and $r e d 1$ at $E_{1 / 2}=-0.71 \mathrm{~V}$ can therefore be either $\mathrm{Cat}^{2-} / \mathrm{SQ}^{-}$or $\mathrm{Co}^{\mathrm{II}} / \mathrm{Co}^{\mathrm{III}}$ based processes in 2 . Similarily, both $o x 1$ at $E_{1 / 2}=-0.32 \mathrm{~V}$ and $o x 2$ at $E_{1 / 2}=+0.37 \mathrm{~V}$ can be either due to $\mathrm{Cat}^{2-} / \mathrm{SQ}^{--}$and $\mathrm{SQ}^{-} / \mathrm{BQ}^{0}$ as well as $\mathrm{Co}^{\mathrm{II}} / \mathrm{Co}^{\mathrm{III}}$ redox processes. The two-electron oxidized species very likely contain at least one fully oxidized ligand $\left(\mathrm{BQ}^{0}\right)$ as in $\left[\mathrm{Co}^{\mathrm{III}}\left(\mathrm{BQ}^{0}\right)\left(\mathrm{SQ}^{--}\right)\right]^{2+}$ or $\left[\mathrm{Co}^{\mathrm{II}}\left(\mathrm{BQ}^{0}\right)\left(\mathrm{BQ}^{0}\right)\right]^{2+}$. The neutral $\mathrm{BQ}^{0}$ is a weakly coordinating ligand ${ }^{8}$ which likely dissociates, thus contributing to the irreversibility of the second oxidation.

Valence tautomeric and dissociation/association equilibria, together with closely spaced redox processes makes the isolation of individual oxidized and reduced species difficult. The twoelectron reduced complex might be the easiest first target for isolation and characterization, which is, however, out of the scope of the present publication dealing with the chemosensing aspect. 
Table S5: Possible assignment of redox processes for $\left[\mathbf{C o}\left({ }^{\mathbf{t}} \mathbf{B u}-\text { dioxolene }\right)_{2}(\mathbf{L})_{2}\right]$ complexes being in a valence tautomeric equilibrium $\left[\mathbf{C o}^{\mathrm{II}}\left(\mathbf{S Q}^{--}\right)\left(\mathbf{S Q}^{--}\right.\right.$ )$\left.(\mathbf{L})_{2}\right] \rightleftarrows\left[\mathbf{C o}^{\text {III }}\left(\mathbf{C a t}^{2-}\right)\left(\mathbf{S Q}^{--}\right)(\mathbf{L})_{2}\right]$ in solution. $\mathbf{L}$ is a monodentate redox-innocent $N$-donor ligand, $\mathbf{C a t}^{2-}$ is the catecholate, $\mathbf{S Q}^{\bullet-}$ the semiquinonate, and $\mathbf{B Q}^{\mathbf{0}}$ the benzoquinonate form of the dioxolene ligand.

\section{$E_{1 / 2}[\mathrm{~V}]$}

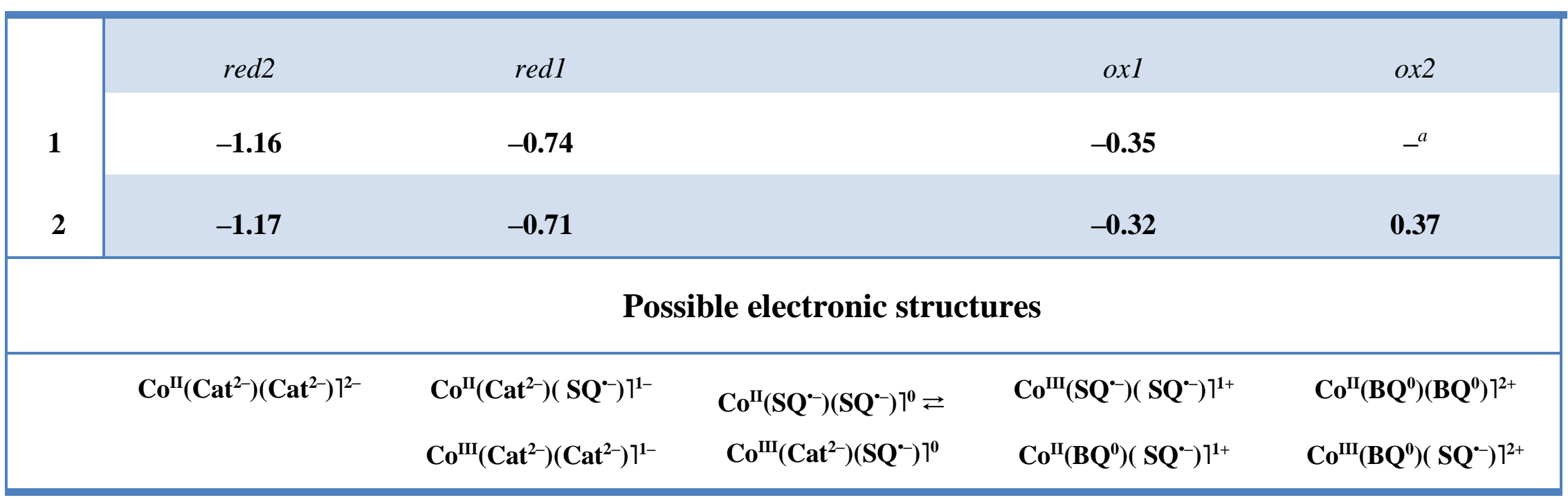

${ }^{a}$ irreversible process 


\section{Theoretical Calculations}

The program ORCA 4.1.1 was used for all calculations. ${ }^{9}$ Geometry optimizations were performed on truncated models with all tert-butyl groups replaced by methyl groups, starting from available X-ray structures if possible. OPBE functional was used throughout. ${ }^{10-11}$ We used def2-TZVP basis set for Co, def2-TZVP(-f) basis sets for the first coordination sphere (N, S) and S atoms, and def2$\mathrm{SV}(\mathrm{P})$ sets for the rest. ${ }^{12}$ To speed up the calculations, RI approximation with def $2 / \mathrm{J}$ auxiliary basis sets $^{13}$ was employed routinely. The $h s-\mathrm{Co}(\mathrm{II})\left(\mathrm{Cat}^{2-}\right)\left(\mathrm{SQ}^{*-}\right)$ states were calculated as $S=5 / 2$. Conductor-like polarizable continuum model $(\mathrm{C}-\mathrm{PCM})^{14}$ was used routinely $($ solvent $=$ benzene $)$. The true minima were confirmed by calculating vibrational frequencies showing no negative values. When calculating thermodynamic parameters, zero-point energy and thermal energy corrections $(T=298.15 \mathrm{~K})$ were applied routinely. 
Table S6:.Calculated thermodynamic parameters.

\begin{tabular}{|c|c|c|c|c|c|c|}
\hline & 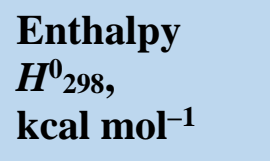 & $\begin{array}{l}\text { Enthalpy } \\
H^{0}{ }_{298} \\
\mathbf{k J ~ m o l}^{-1}\end{array}$ & $\begin{array}{l}\text { Entropic term } \\
T S_{298}^{0}, \mathrm{kcal} \mathrm{mol}^{-1} \\
(T=298 \mathrm{~K})\end{array}$ & $\begin{array}{l}\text { Entropy } S^{0_{298}} \\
\mathrm{~J} \mathrm{~K}^{-1} \mathrm{~mol}^{-1}\end{array}$ & 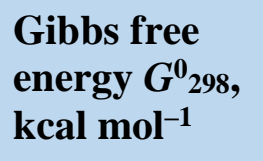 & 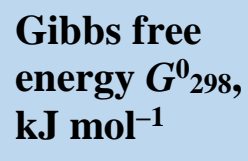 \\
\hline \multicolumn{7}{|c|}{$\begin{array}{l}\text { 1: } \\
\text { Co(dioxolene })_{2}(\text { stypy })_{2}\end{array}$} \\
\hline$h s-\mathrm{Co}(\mathrm{II})$ & -2142486.78 & -8964164.69 & 80.05 & 1123.4 & -2142566.83 & -8964499.63 \\
\hline$l s-\mathrm{Co}(\mathrm{III})$ & -2142496.42 & -8964205.01 & 77.90 & 1093.2 & -2142574.32 & -8964530.94 \\
\hline $\operatorname{delta}(h s-l s)$ & 9.64 & 40.32 & 2.15 & 30.2 & $\mathbf{7 . 4 8}$ & 31.31 \\
\hline \multicolumn{7}{|c|}{$\begin{array}{l}\text { 2: } \\
\text { Co(dioxolene })_{2}(\text { py })_{2}\end{array}$} \\
\hline$h s-\mathrm{Co}(\mathrm{II})$ & -1755959.41 & -7346934.19 & 61.28 & 859.9 & -1756020.69 & -7347190.58 \\
\hline$l s-\mathrm{Co}(\mathrm{III})$ & -1755968.48 & -7346972.11 & 57.65 & 809.1 & -1756026.13 & -7347213.34 \\
\hline $\operatorname{delta}(h s-l s)$ & 9.06 & $\mathbf{3 7 . 9 2}$ & 3.62 & 50.9 & 5.44 & 22.76 \\
\hline \multicolumn{7}{|c|}{$\mathrm{Co}(\text { dioxolene })_{2}(\mathrm{DMSO})_{2}$} \\
\hline$h s-\mathrm{Co}(\mathrm{II})$ & -2138794.84 & -8948717.63 & 65.50 & 919.2 & -2138860.35 & -8948991.69 \\
\hline$l s-\mathrm{Co}(\mathrm{III})$ & -2138792.80 & -8948709.06 & 60.84 & 853.8 & -2138853.64 & -8948963.61 \\
\hline $\operatorname{delta}(h s-l s)$ & -2.05 & -8.57 & 4.66 & 65.4 & -6.71 & -28.08 \\
\hline
\end{tabular}


Optimized geometry for 1 : $h s-\operatorname{Co}\left(\right.$ II) state, $S=5 / 2,\left\langle\mathrm{~S}^{2}\right\rangle=8.772033$

\begin{tabular}{|c|c|c|c|}
\hline Co & 2.589402 & 3.544813 & 5.657785 \\
\hline $\mathrm{O}$ & 3.927546 & 4.516787 & 4.472912 \\
\hline $\mathrm{O}$ & 2.252171 & 2.573296 & 3.898217 \\
\hline $\mathrm{C}$ & 3.938330 & 4.077261 & 3.254680 \\
\hline $\mathrm{C}$ & 4.800501 & 4.575317 & 2.242968 \\
\hline $\mathrm{C}$ & 4.734671 & 4.070831 & 0.946333 \\
\hline $\mathrm{C}$ & 3.789122 & 3.042096 & 0.647915 \\
\hline $\mathrm{C}$ & 2.920686 & 2.503807 & 1.592441 \\
\hline $\mathrm{C}$ & 2.988702 & 3.012752 & 2.930849 \\
\hline $\mathrm{C}$ & 1.935882 & 1.421187 & 1.260607 \\
\hline $\mathrm{N}$ & 1.064571 & 5.095678 & 5.141417 \\
\hline $\mathrm{C}$ & 1.342409 & 6.407534 & 5.216632 \\
\hline $\mathrm{C}$ & 0.418547 & 7.402084 & 4.906140 \\
\hline $\mathrm{C}$ & -0.886336 & 7.060732 & 4.487044 \\
\hline $\mathrm{C}$ & -1.161092 & 5.676666 & 4.412808 \\
\hline $\mathrm{C}$ & -0.174802 & 4.753484 & 4.743095 \\
\hline $\mathrm{C}$ & -1.838070 & 8.120802 & 4.167321 \\
\hline $\mathrm{C}$ & -3.126878 & 7.963556 & 3.757727 \\
\hline $\mathrm{C}$ & -4.097581 & 9.007394 & 3.432593 \\
\hline $\mathrm{C}$ & -3.821865 & 10.393933 & 3.503451 \\
\hline $\mathrm{C}$ & -4.796471 & 11.337572 & 3.178138 \\
\hline $\mathrm{C}$ & -6.075726 & 10.929487 & 2.772269 \\
\hline $\mathrm{C}$ & -6.369860 & 9.563065 & 2.695398 \\
\hline $\mathrm{C}$ & -5.394146 & 8.617784 & 3.021134 \\
\hline $\mathrm{O}$ & 1.251527 & 2.572277 & 6.842237 \\
\hline $\mathrm{O}$ & 2.926398 & 4.515926 & 7.417971 \\
\hline $\mathrm{C}$ & 1.241553 & 3.010263 & 8.061031 \\
\hline $\mathrm{C}$ & 0.380592 & 2.510347 & 9.072860 \\
\hline $\mathrm{C}$ & 0.447247 & 3.013201 & 10.370079 \\
\hline $\mathrm{C}$ & 1.392421 & 4.042153 & 10.668961 \\
\hline $\mathrm{C}$ & 2.259722 & 4.582168 & 9.724379 \\
\hline $\mathrm{C}$ & 2.190880 & 4.074897 & 8.385370 \\
\hline $\mathrm{C}$ & -0.449700 & 2.496737 & 11.461118 \\
\hline $\mathrm{C}$ & 3.244166 & 5.664948 & 10.056757 \\
\hline $\mathrm{N}$ & 4.114994 & 1.994370 & 6.174637 \\
\hline $\mathrm{C}$ & 3.837691 & 0.682402 & 6.099443 \\
\hline $\mathrm{C}$ & 4.761841 & -0.311770 & 6.410301 \\
\hline $\mathrm{C}$ & 6.066460 & 0.030120 & 6.829774 \\
\hline $\mathrm{C}$ & 6.340667 & 1.414299 & 6.903956 \\
\hline $\mathrm{C}$ & 5.354120 & 2.337071 & 6.573283 \\
\hline $\mathrm{C}$ & 7.018491 & -1.029561 & 7.149909 \\
\hline $\mathrm{C}$ & 8.307125 & -0.871793 & 7.559847 \\
\hline $\mathrm{C}$ & 9.278110 & -1.915236 & 7.885404 \\
\hline $\mathrm{C}$ & 9.002906 & -3.301884 & 7.814687 \\
\hline
\end{tabular}




$\begin{array}{cccc}\mathrm{C} & 9.977758 & -4.245126 & 8.140408 \\ \mathrm{C} & 11.256760 & -3.836525 & 8.546554 \\ \mathrm{C} & 11.550389 & -2.469987 & 8.623293 \\ \mathrm{C} & 10.574426 & -1.525102 & 8.297149 \\ \mathrm{C} & 5.633091 & 4.585161 & -0.144504 \\ \mathrm{H} & 5.512907 & 5.367731 & 2.506546 \\ \mathrm{H} & 3.748445 & 2.656463 & -0.380953 \\ \mathrm{H} & 2.356252 & 6.668266 & 5.541760 \\ \mathrm{H} & 0.718143 & 8.454396 & 4.991394 \\ \mathrm{H} & -2.140914 & 5.300043 & 4.098614 \\ \mathrm{H} & -0.382447 & 3.678085 & 4.688080 \\ \mathrm{H} & -1.434773 & 9.136541 & 4.282070 \\ \mathrm{H} & -3.518085 & 6.941862 & 3.647685 \\ \mathrm{H} & -2.831572 & 10.745526 & 3.817545 \\ \mathrm{H} & -4.556191 & 12.407713 & 3.241628 \\ \mathrm{H} & -6.839635 & 11.676555 & 2.517204 \\ \mathrm{H} & -7.367633 & 9.229649 & 2.379081 \\ \mathrm{H} & -5.635889 & 7.547877 & 2.957300 \\ \mathrm{H} & -0.331563 & 1.717846 & 8.808867 \\ \mathrm{H} & 1.433762 & 4.426505 & 11.698283 \\ \mathrm{H} & 2.824045 & 0.421249 & 5.774035 \\ \mathrm{H} & 4.462678 & -1.364205 & 6.325042 \\ \mathrm{H} & 7.320246 & 1.791324 & 7.218426 \\ \mathrm{H} & 5.561339 & 3.412554 & 6.628260 \\ \mathrm{H} & 6.615595 & -2.045461 & 7.035176 \\ \mathrm{H} & 8.697933 & 0.150058 & 7.669851 \\ \mathrm{H} & 8.012820 & -3.653874 & 7.500386 \\ \mathrm{H} & 9.737876 & -5.315362 & 8.077018 \\ \mathrm{H} & 12.020867 & -4.583283 & 8.801934 \\ \mathrm{H} & 12.547959 & -2.136167 & 8.939823 \\ \mathrm{H} & 10.815774 & -0.455100 & 8.360882 \\ \mathrm{H} & 5.044149 & 5.004528 & -0.985987 \\ \mathrm{H} & 6.254895 & 3.770983 & -0.570290 \\ \mathrm{H} & 6.313024 & 5.375784 & 0.221347 \\ \mathrm{H} & 0.896961 & 1.742292 & 1.475846 \\ \mathrm{H} & 2.112438 & 0.515014 & 1.874278 \\ \mathrm{H} & 1.995432 & 1.134193 & 0.194961 \\ \mathrm{H} & 3.066656 & 6.571737 & 9.444273 \\ \mathrm{H} & 4.283107 & 5.344672 & 9.840380 \\ & -1.185248 & 5.950659 & 11.122783 \\ \mathrm{H} & 0.140390 & 2.074820 & 12.300537 \\ \mathrm{H} & & & \\ \mathrm{H} & & & \\ \mathrm{H} & & & \end{array}$


Optimized geometry for 1 : $l s-\mathrm{Co}$ (III) state, $S=1 / 2,\left\langle\mathrm{~S}^{2}\right\rangle=0.752306$

\begin{tabular}{|c|c|c|c|}
\hline Co & 2.810795 & 4.524294 & 4.755291 \\
\hline $\mathrm{O}$ & 2.151853 & 5.899750 & 3.647883 \\
\hline $\mathrm{O}$ & 3.665056 & 5.868986 & 5.758070 \\
\hline $\mathrm{O}$ & 3.469693 & 3.148862 & 5.862515 \\
\hline $\mathrm{O}$ & 1.956572 & 3.180009 & 3.752375 \\
\hline $\mathrm{N}$ & 1.220500 & 4.683053 & 5.895760 \\
\hline $\mathrm{N}$ & 4.401314 & 4.365637 & 3.614674 \\
\hline $\mathrm{C}$ & 2.578371 & 7.077694 & 4.077383 \\
\hline $\mathrm{C}$ & 2.253148 & 8.299995 & 3.455394 \\
\hline $\mathrm{C}$ & 2.746924 & 9.503486 & 3.975399 \\
\hline $\mathrm{C}$ & 3.570730 & 9.462552 & 5.128222 \\
\hline $\mathrm{C}$ & 3.919276 & 8.272048 & 5.778410 \\
\hline $\mathrm{C}$ & 3.411735 & 7.060254 & 5.239614 \\
\hline $\mathrm{C}$ & 2.421105 & 10.824436 & 3.329116 \\
\hline $\mathrm{C}$ & 3.043417 & 1.970893 & 5.432668 \\
\hline $\mathrm{C}$ & 3.367413 & 0.748665 & 6.055282 \\
\hline $\mathrm{C}$ & 2.872804 & -0.454716 & 5.535622 \\
\hline $\mathrm{C}$ & 2.048270 & -0.413482 & 4.383422 \\
\hline $\mathrm{C}$ & 1.700865 & 0.777096 & 3.732609 \\
\hline $\mathrm{C}$ & 2.210182 & 1.988540 & 4.270344 \\
\hline $\mathrm{C}$ & 0.824615 & 0.802455 & 2.512804 \\
\hline $\mathrm{C}$ & 1.330651 & 4.719026 & 7.237745 \\
\hline $\mathrm{C}$ & 0.232704 & 4.835132 & 8.079489 \\
\hline $\mathrm{C}$ & -1.072102 & 4.921772 & 7.543810 \\
\hline $\mathrm{C}$ & -1.155628 & 4.879513 & 6.134572 \\
\hline $\mathrm{C}$ & -0.008948 & 4.762005 & 5.357770 \\
\hline $\mathrm{C}$ & -2.293491 & 5.048162 & 8.331135 \\
\hline $\mathrm{C}$ & -2.385119 & 5.109537 & 9.688517 \\
\hline $\mathrm{C}$ & -3.594329 & 5.237510 & 10.499422 \\
\hline $\mathrm{C}$ & -3.459192 & 5.286515 & 11.907148 \\
\hline $\mathrm{C}$ & -4.572854 & 5.408500 & 12.741569 \\
\hline $\mathrm{C}$ & -5.857092 & 5.485026 & 12.189829 \\
\hline $\mathrm{C}$ & -6.013508 & 5.438134 & 10.796553 \\
\hline $\mathrm{C}$ & -4.901810 & 5.316396 & 9.962841 \\
\hline $\mathrm{C}$ & 4.291184 & 4.329617 & 2.272701 \\
\hline $\mathrm{C}$ & 5.389160 & 4.213676 & 1.430960 \\
\hline $\mathrm{C}$ & 6.693968 & 4.127236 & 1.966664 \\
\hline $\mathrm{C}$ & 6.777467 & 4.169501 & 3.375905 \\
\hline $\mathrm{C}$ & 5.630749 & 4.286844 & 4.152685 \\
\hline $\mathrm{C}$ & 7.915398 & 4.001033 & 1.179363 \\
\hline $\mathrm{C}$ & 8.007047 & 3.939519 & -0.178010 \\
\hline $\mathrm{C}$ & 9.216287 & 3.811711 & -0.988900 \\
\hline $\mathrm{C}$ & 9.081151 & 3.762421 & -2.396615 \\
\hline $\mathrm{C}$ & 10.194837 & 3.640562 & -3.231024 \\
\hline
\end{tabular}




$\begin{array}{cccc}\mathrm{C} & 11.479098 & 3.564455 & -2.679282 \\ \mathrm{C} & 11.635514 & 3.611644 & -1.286016 \\ \mathrm{C} & 10.523792 & 3.733254 & -0.452317 \\ \mathrm{C} & 4.793253 & 8.247076 & 6.999849 \\ \mathrm{C} & 3.212346 & -1.776885 & 6.172295 \\ \mathrm{H} & 1.611681 & 8.288547 & 2.564698 \\ \mathrm{H} & 3.956309 & 10.408589 & 5.534525 \\ \mathrm{H} & 4.008161 & 0.759985 & 6.946503 \\ \mathrm{H} & 1.660471 & -1.359167 & 3.978433 \\ \mathrm{H} & 2.346019 & 4.651027 & 7.637177 \\ \mathrm{H} & 0.416067 & 4.856040 & 9.159149 \\ \mathrm{H} & -2.128154 & 4.939844 & 5.630661 \\ \mathrm{H} & -0.060643 & 4.729221 & 4.266281 \\ \mathrm{H} & -3.212505 & 5.097191 & 7.731034 \\ \mathrm{H} & -1.457506 & 5.060654 & 10.276820 \\ \mathrm{H} & -2.455686 & 5.227316 & 12.350556 \\ \mathrm{H} & -4.436587 & 5.444041 & 13.830994 \\ \mathrm{H} & -6.735908 & 5.581052 & 12.841858 \\ \mathrm{H} & -7.017550 & 5.497409 & 10.354663 \\ \mathrm{H} & -5.057596 & 5.282467 & 8.877740 \\ \mathrm{H} & 3.275803 & 4.397429 & 1.873261 \\ \mathrm{H} & 5.205801 & 4.192721 & 0.351299 \\ \mathrm{H} & 7.749990 & 4.109296 & 3.879839 \\ \mathrm{H} & 5.682431 & 4.319607 & 5.244181 \\ \mathrm{H} & 8.834420 & 3.952263 & 1.779474 \\ \mathrm{H} & 7.079424 & 3.988124 & -0.766320 \\ \mathrm{H} & 8.077627 & 3.821295 & -2.840026 \\ \mathrm{H} & 10.058566 & 3.604789 & -4.320441 \\ \mathrm{H} & 12.357932 & 3.468532 & -3.331303 \\ \mathrm{H} & 12.639576 & 3.552710 & -0.844124 \\ \mathrm{H} & 10.679583 & 3.767431 & 0.632776 \\ \mathrm{H} & 1.939250 & 11.519985 & 4.046258 \\ \mathrm{H} & 1.737878 & 10.701918 & 2.468680 \\ \mathrm{H} & 3.336205 & 11.332842 & 2.961036 \\ \mathrm{H} & 4.271916 & 7.785843 & 7.862947 \\ \mathrm{H} & 5.103910 & 9.266731 & 7.292441 \\ \mathrm{H} & 5.708466 & 7.643987 & 6.832077 \\ \mathrm{H} & -0.088557 & 1.408461 & 2.681125 \\ & 0.510593 & -0.216831 & 2.222521 \\ \mathrm{H} & 1.345705 & 1.260643 & 1.647919 \\ \mathrm{H} & 3.780052 & -2.361857 & 6.407020 \\ & -1.645333 & 7.111801 \\ \mathrm{H} & & & \\ \mathrm{H} & & & \end{array}$


Optimized geometry for 2 : $h s-\mathrm{Co}(\mathrm{II})$ state, $S=5 / 2,\left\langle\mathrm{~S}^{2}\right\rangle=8.768022$

\begin{tabular}{|c|c|c|c|}
\hline Co & 2.589846 & 3.544313 & 5.658068 \\
\hline $\mathrm{O}$ & 3.926319 & 4.516920 & 4.474838 \\
\hline $\mathrm{O}$ & 2.253194 & 2.573778 & 3.901177 \\
\hline $\mathrm{C}$ & 3.937220 & 4.078502 & 3.255904 \\
\hline $\mathrm{C}$ & 4.797875 & 4.578227 & 2.243989 \\
\hline $\mathrm{C}$ & 4.731355 & 4.073932 & 0.947275 \\
\hline $\mathrm{C}$ & 3.786796 & 3.044008 & 0.649421 \\
\hline $\mathrm{C}$ & 2.919715 & 2.504283 & 1.594378 \\
\hline $\mathrm{C}$ & 2.988462 & 3.013375 & 2.932506 \\
\hline $\mathrm{C}$ & 1.935941 & 1.420575 & 1.263060 \\
\hline $\mathrm{N}$ & 1.055573 & 5.104151 & 5.138087 \\
\hline $\mathrm{C}$ & 1.344659 & 6.413331 & 5.217294 \\
\hline $\mathrm{C}$ & 0.423351 & 7.415223 & 4.904222 \\
\hline $\mathrm{C}$ & -0.858690 & 7.044699 & 4.488870 \\
\hline $\mathrm{C}$ & -1.163857 & 5.683465 & 4.404847 \\
\hline $\mathrm{C}$ & -0.177816 & 4.752394 & 4.738643 \\
\hline $\mathrm{O}$ & 1.253456 & 2.571364 & 6.840905 \\
\hline $\mathrm{O}$ & 2.926318 & 4.514520 & 7.415356 \\
\hline $\mathrm{C}$ & 1.242937 & 3.008863 & 8.060176 \\
\hline $\mathrm{C}$ & 0.382858 & 2.508095 & 9.072065 \\
\hline $\mathrm{C}$ & 0.449786 & 3.011394 & 10.369142 \\
\hline $\mathrm{C}$ & 1.394173 & 4.041366 & 10.667379 \\
\hline $\mathrm{C}$ & 2.260700 & 4.582074 & 9.722474 \\
\hline $\mathrm{C}$ & 2.191550 & 4.074002 & 8.383974 \\
\hline $\mathrm{C}$ & -0.446281 & 2.494650 & 11.460677 \\
\hline $\mathrm{C}$ & 3.244307 & 5.665799 & 10.054207 \\
\hline $\mathrm{N}$ & 4.124631 & 1.984777 & 6.178249 \\
\hline $\mathrm{C}$ & 3.835849 & 0.675520 & 6.099210 \\
\hline $\mathrm{C}$ & 4.757403 & -0.326122 & 6.412364 \\
\hline $\mathrm{C}$ & 6.039373 & 0.044750 & 6.827624 \\
\hline $\mathrm{C}$ & 6.344225 & 1.406065 & 6.911476 \\
\hline $\mathrm{C}$ & 5.357954 & 2.336865 & 6.577605 \\
\hline $\mathrm{C}$ & 5.628076 & 4.589535 & -0.144261 \\
\hline $\mathrm{H}$ & 5.509612 & 5.371361 & 2.507108 \\
\hline $\mathrm{H}$ & 3.745785 & 2.658668 & -0.379519 \\
\hline $\mathrm{H}$ & 2.360181 & 6.662896 & 5.546143 \\
\hline $\mathrm{H}$ & 0.715493 & 8.469742 & 4.987294 \\
\hline $\mathrm{H}$ & -2.154866 & 5.337589 & 4.084673 \\
\hline $\mathrm{H}$ & -0.379139 & 3.675576 & 4.686114 \\
\hline $\mathrm{H}$ & -0.328757 & 1.714957 & 8.808627 \\
\hline $\mathrm{H}$ & 1.435518 & 4.425921 & 11.696600 \\
\hline $\mathrm{H}$ & 2.820369 & 0.425679 & 5.770437 \\
\hline $\mathrm{H}$ & 4.465505 & -1.380720 & 6.329429 \\
\hline $\mathrm{H}$ & 7.335165 & 1.752211 & 7.231573 \\
\hline
\end{tabular}




$\begin{array}{lrrc}\mathrm{H} & 5.559030 & 3.413735 & 6.630001 \\ \mathrm{H} & 5.037741 & 5.006981 & -0.985689 \\ \mathrm{H} & 6.251278 & 3.776345 & -0.569864 \\ \mathrm{H} & 6.306545 & 5.381799 & 0.220687 \\ \mathrm{H} & 0.896810 & 1.740246 & 1.479331 \\ \mathrm{H} & 2.114222 & 0.514342 & 1.876130 \\ \mathrm{H} & 1.994881 & 1.134082 & 0.197277 \\ \mathrm{H} & 3.065583 & 6.572389 & 9.441799 \\ \mathrm{H} & 4.283447 & 5.346544 & 9.837357 \\ \mathrm{H} & 3.185665 & 5.951551 & 11.120206 \\ \mathrm{H} & -1.069371 & 3.307348 & 11.887375 \\ \mathrm{H} & 0.144567 & 2.076487 & 12.301391 \\ \mathrm{H} & -1.124827 & 1.702627 & 11.095352 \\ \mathrm{H} & -1.608968 & 7.805625 & 4.234399 \\ \mathrm{H} & 6.789838 & -0.715972 & 7.082156\end{array}$


Optimized geometry for 2 : $l s$-Co(III) state, $S=1 / 2,\left\langle\mathrm{~S}^{2}\right\rangle=0.752132$

\begin{tabular}{|c|c|c|c|}
\hline $\mathrm{Co}$ & 2.810827 & 4.524399 & 4.755099 \\
\hline $\mathrm{O}$ & 2.150157 & 5.899961 & 3.650060 \\
\hline $\mathrm{O}$ & 3.666577 & 5.868756 & 5.756106 \\
\hline $\mathrm{O}$ & 3.471538 & 3.148852 & 5.860059 \\
\hline $\mathrm{O}$ & 1.955037 & 3.180136 & 3.754080 \\
\hline $\mathrm{N}$ & 1.219467 & 4.682613 & 5.902100 \\
\hline $\mathrm{N}$ & 4.402324 & 4.366148 & 3.608016 \\
\hline $\mathrm{C}$ & 2.578278 & 7.078412 & 4.077678 \\
\hline $\mathrm{C}$ & 2.253219 & 8.300298 & 3.455086 \\
\hline $\mathrm{C}$ & 2.748770 & 9.503572 & 3.973909 \\
\hline $\mathrm{C}$ & 3.573533 & 9.462530 & 5.126126 \\
\hline $\mathrm{C}$ & 3.921992 & 8.272222 & 5.776712 \\
\hline $\mathrm{C}$ & 3.413281 & 7.060777 & 5.238437 \\
\hline $\mathrm{C}$ & 2.423784 & 10.824407 & 3.327115 \\
\hline $\mathrm{C}$ & 3.043720 & 1.970351 & 5.432193 \\
\hline $\mathrm{C}$ & 3.367727 & 0.748594 & 6.055476 \\
\hline $\mathrm{C}$ & 2.871394 & -0.454638 & 5.537157 \\
\hline $\mathrm{C}$ & 2.045845 & -0.413465 & 4.385573 \\
\hline $\mathrm{C}$ & 1.698389 & 0.776806 & 3.734283 \\
\hline $\mathrm{C}$ & 2.208799 & 1.988020 & 4.271357 \\
\hline $\mathrm{C}$ & 0.821139 & 0.801833 & 2.515198 \\
\hline $\mathrm{C}$ & 1.343801 & 4.714920 & 7.240285 \\
\hline $\mathrm{C}$ & 0.240022 & 4.827388 & 8.085119 \\
\hline $\mathrm{C}$ & -1.037879 & 4.909284 & 7.526504 \\
\hline $\mathrm{C}$ & -1.158530 & 4.874764 & 6.135082 \\
\hline $\mathrm{C}$ & -0.006996 & 4.760746 & 5.356963 \\
\hline $\mathrm{C}$ & 4.277997 & 4.333725 & 2.269842 \\
\hline $\mathrm{C}$ & 5.381784 & 4.221241 & 1.425016 \\
\hline $\mathrm{C}$ & 6.659685 & 4.139444 & 1.983651 \\
\hline $\mathrm{C}$ & 6.780328 & 4.174076 & 3.375073 \\
\hline $\mathrm{C}$ & 5.628777 & 4.288106 & 4.153169 \\
\hline $\mathrm{C}$ & 4.796895 & 8.247442 & 6.997485 \\
\hline $\mathrm{C}$ & 3.209202 & -1.776570 & 6.175099 \\
\hline $\mathrm{H}$ & 1.610862 & 8.288923 & 2.565064 \\
\hline $\mathrm{H}$ & 3.960174 & 10.408446 & 5.531614 \\
\hline $\mathrm{H}$ & 4.009448 & 0.760016 & 6.945962 \\
\hline $\mathrm{H}$ & 1.657165 & -1.359139 & 3.981494 \\
\hline $\mathrm{H}$ & 2.362919 & 4.647644 & 7.630212 \\
\hline $\mathrm{H}$ & 0.394789 & 4.849219 & 9.170872 \\
\hline $\mathrm{H}$ & -2.136289 & 4.935457 & 5.641548 \\
\hline $\mathrm{H}$ & -0.050354 & 4.730025 & 4.265035 \\
\hline $\mathrm{H}$ & 3.258869 & 4.400913 & 1.879913 \\
\hline $\mathrm{H}$ & 5.227027 & 4.199323 & 0.339263 \\
\hline $\mathrm{H}$ & 7.758088 & 4.113453 & 3.868615 \\
\hline
\end{tabular}




$\begin{array}{lrrc}\mathrm{H} & 5.672109 & 4.318897 & 5.245099 \\ \mathrm{H} & 1.940499 & 11.519714 & 4.043495 \\ \mathrm{H} & 1.742273 & 10.701818 & 2.465380 \\ \mathrm{H} & 3.339565 & 11.333003 & 2.961147 \\ \mathrm{H} & 4.275879 & 7.787200 & 7.861280 \\ \mathrm{H} & 5.108286 & 9.267089 & 7.289154 \\ \mathrm{H} & 5.711671 & 7.643810 & 6.829485 \\ \mathrm{H} & -0.092743 & 1.406438 & 2.684599 \\ \mathrm{H} & 0.508230 & -0.217660 & 2.224617 \\ \mathrm{H} & 1.340973 & 1.261123 & 1.650188 \\ \mathrm{H} & 2.295693 & -2.356281 & 6.418027 \\ \mathrm{H} & 3.784125 & -1.645094 & 7.110150 \\ \mathrm{H} & 3.815795 & -2.411028 & 5.495872 \\ \mathrm{H} & -1.926292 & 4.998687 & 8.165756 \\ \mathrm{H} & 7.548107 & 4.050028 & 1.344412\end{array}$


Optimized geometry for $\left[\mathrm{Co}(\text { dioxolene })_{2}(\mathrm{DMSO})_{2}\right]: h s-\mathrm{Co}(\mathrm{II})$ state, $S=5 / 2,\left\langle\mathrm{~S}^{2}\right\rangle=8.760518$

$\begin{array}{cccc}\mathrm{Co} & 2.592864 & 3.559793 & 5.654668 \\ \mathrm{O} & 3.799392 & 4.639940 & 4.433995 \\ \mathrm{O} & 2.227317 & 2.592145 & 3.909611 \\ \mathrm{C} & 3.881996 & 4.125457 & 3.247453 \\ \mathrm{C} & 4.754777 & 4.608295 & 2.237994 \\ \mathrm{C} & 4.769639 & 4.021331 & 0.974450 \\ \mathrm{C} & 3.892672 & 2.925746 & 0.706565 \\ \mathrm{C} & 3.013751 & 2.401878 & 1.649591 \\ \mathrm{C} & 2.997767 & 2.996952 & 2.954267 \\ \mathrm{C} & 2.101264 & 1.248505 & 1.351360 \\ \mathrm{O} & 1.385766 & 2.479731 & 6.874605 \\ \mathrm{O} & 2.959358 & 4.525346 & 7.401910 \\ \mathrm{C} & 1.316389 & 2.981168 & 8.067561 \\ \mathrm{C} & 0.455258 & 2.486844 & 9.081457 \\ \mathrm{C} & 0.453235 & 3.061185 & 10.350831 \\ \mathrm{C} & 1.331216 & 4.155717 & 10.619953 \\ \mathrm{C} & 2.198777 & 4.690691 & 9.672703 \\ \mathrm{C} & 2.201767 & 4.108410 & 8.362104 \\ \mathrm{C} & -0.451000 & 2.556347 & 11.441300 \\ \mathrm{C} & 3.112160 & 5.842981 & 9.972317 \\ \mathrm{C} & 5.686553 & 4.513934 & -0.111027 \\ \mathrm{H} & 5.414796 & 5.451977 & 2.477965 \\ \mathrm{H} & 3.916473 & 2.474341 & -0.295833 \\ \mathrm{H} & -0.205979 & 1.644479 & 8.840237 \\ \mathrm{H} & 1.317558 & 4.597126 & 11.626984 \\ \mathrm{H} & 5.114294 & 4.841557 & -1.003240 \\ \mathrm{H} & 6.371172 & 3.711011 & -0.453848 \\ \mathrm{H} & 6.304712 & 5.365060 & 0.227700 \\ \mathrm{H} & 1.039051 & 1.525183 & 1.505783 \\ \mathrm{H} & 2.298152 & 0.394660 & 2.030375 \\ \mathrm{H} & 2.220502 & 0.897689 & 0.310031 \\ \mathrm{H} & 2.905965 & 6.703054 & 9.304009 \\ \mathrm{H} & 4.173180 & 5.570167 & 9.803482 \\ \mathrm{H} & 3.003649 & 6.183173 & 11.018334 \\ \mathrm{H} & -1.133869 & 3.354407 & 11.798674 \\ \mathrm{H} & 0.131386 & 2.221917 & 12.324378 \\ \mathrm{H} & -1.070734 & 1.706912 & 11.101206 \\ & 0.703291 & 5.935308 & 4.201237 \\ \mathrm{O} & 0.844954 & 4.983706 & 5.373335 \\ \mathrm{H} & 1.144372 & 7.567714 & 4.814671 \\ \mathrm{H} & -1.43564 & 5.223145 & 3.670329 \\ \mathrm{H} & 6.959197 & 3.234548 \\ \mathrm{H} & 6.484195 & 4.975285\end{array}$

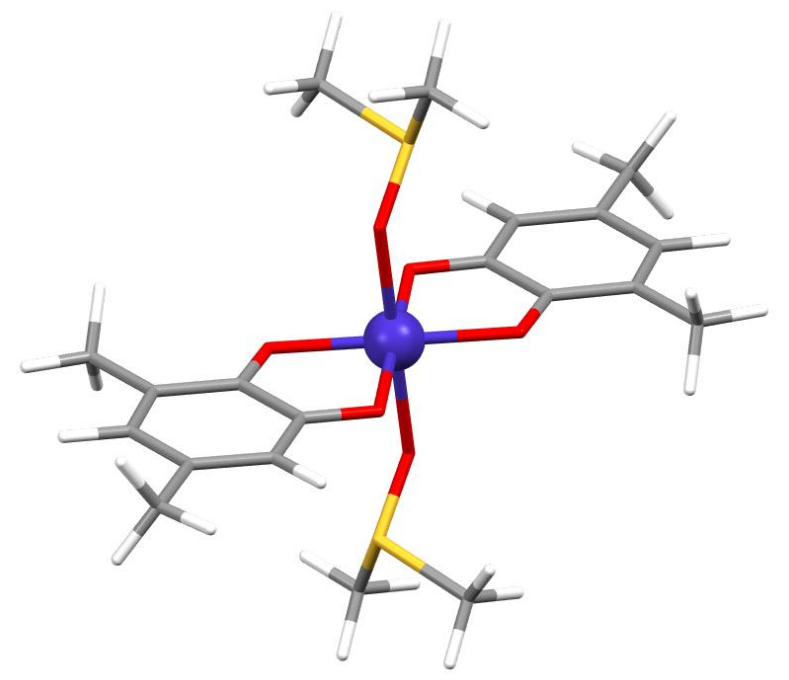




$\begin{array}{lccc}\mathrm{H} & 2.226253 & 7.531355 & 5.035467 \\ \mathrm{H} & 0.570718 & 7.797200 & 5.731495 \\ \mathrm{H} & 0.950143 & 8.310864 & 4.019204 \\ \mathrm{~S} & 4.477298 & 1.172856 & 7.097876 \\ \mathrm{O} & 4.341894 & 2.138509 & 5.936559 \\ \mathrm{C} & 4.041510 & -0.452466 & 6.462151 \\ \mathrm{C} & 6.244865 & 0.919610 & 7.297262 \\ \mathrm{H} & 2.961055 & -0.414273 & 6.234771 \\ \mathrm{H} & 4.231117 & -1.204893 & 7.249976 \\ \mathrm{H} & 4.621310 & -0.670605 & 5.546423 \\ \mathrm{H} & 6.660010 & 1.880541 & 7.651025 \\ \mathrm{H} & 6.700015 & 0.636069 & 6.330417 \\ \mathrm{H} & 6.407034 & 0.138837 & 8.063282\end{array}$


Optimized geometry for $\left[\mathrm{Co}(\text { dioxolene })_{2}(\mathrm{DMSO})_{2}\right]: l s-\mathrm{Co}(\mathrm{III})$ state, $S=1 / 2,\left\langle\mathrm{~S}^{2}\right\rangle=0.752429$

$\begin{array}{lrcc}\text { Co } & 2.586630 & 3.554706 & 5.659802 \\ \mathrm{O} & 3.760500 & 4.460661 & 4.507101 \\ \mathrm{O} & 2.153886 & 2.447448 & 4.208211 \\ \mathrm{C} & 3.727460 & 3.917004 & 3.300455 \\ \mathrm{C} & 4.505255 & 4.370821 & 2.215178 \\ \mathrm{C} & 4.399167 & 3.744716 & 0.965780 \\ \mathrm{C} & 3.500247 & 2.658932 & 0.820611 \\ \mathrm{C} & 2.710229 & 2.173325 & 1.871194 \\ \mathrm{C} & 2.832877 & 2.813775 & 3.132927 \\ \mathrm{C} & 1.757822 & 1.024139 & 1.698881 \\ \mathrm{O} & 1.413127 & 2.648218 & 6.812437 \\ \mathrm{O} & 3.019568 & 4.661513 & 7.111654 \\ \mathrm{C} & 1.447453 & 3.190526 & 8.019673 \\ \mathrm{C} & 0.671314 & 2.735065 & 9.105439 \\ \mathrm{C} & 0.778913 & 3.359617 & 10.355486 \\ \mathrm{C} & 1.677716 & 4.445466 & 10.500802 \\ \mathrm{C} & 2.466172 & 4.932619 & 9.449748 \\ \mathrm{C} & 2.341955 & 4.293770 & 8.187369 \\ \mathrm{C} & -0.040339 & 2.896212 & 11.532015 \\ \mathrm{C} & 3.418488 & 6.081858 & 9.622236 \\ \mathrm{C} & 5.220297 & 4.206263 & -0.210170 \\ \mathrm{~S} & 1.382969 & 6.244897 & 5.098291 \\ \mathrm{O} & 1.094193 & 4.731678 & 5.142765 \\ \mathrm{C} & 0.851473 & 6.750814 & 3.464015 \\ \mathrm{C} & 0.064283 & 6.968629 & 6.071389 \\ \mathrm{~S} & 3.791110 & 0.864412 & 6.223205 \\ \mathrm{O} & 4.079729 & 2.377545 & 6.176843 \\ \mathrm{C} & 5.109973 & 0.139592 & 5.251136 \\ \mathrm{C} & 4.322519 & 0.360432 & 7.858127 \\ \mathrm{H} & 5.189919 & 5.214962 & 2.369914 \\ \mathrm{H} & 3.415134 & 2.172025 & -0.161590 \\ \mathrm{H} & -0.013311 & 1.890919 & 8.950560 \\ \mathrm{H} & 1.764061 & 4.931142 & 11.483504 \\ \mathrm{H} & 4.577422 & 4.516300 & -1.059576 \\ \mathrm{H} & 5.877355 & 3.397060 & -0.590334 \\ \mathrm{H} & 5.865543 & 5.064649 & 0.052825 \\ \mathrm{H} & 0.718306 & 1.319412 & 1.946786 \\ \mathrm{H} & 2.007517 & 0.181796 & 2.375477 \\ \mathrm{H} & 1.769545 & 0.644383 & 0.660770 \\ \mathrm{H} & 3.167433 & 6.925134 & 8.947303 \\ \mathrm{H} & 4.457700 & 5.787299 & 9.372218 \\ \mathrm{H} & 3.408309 & 6.460076 & 10.660925 \\ \mathrm{H} & -0.695966 & 3.705136 & 11.915197 \\ \mathrm{H} & 0.603910 & 2.583782 & 12.379513 \\ & & & \end{array}$

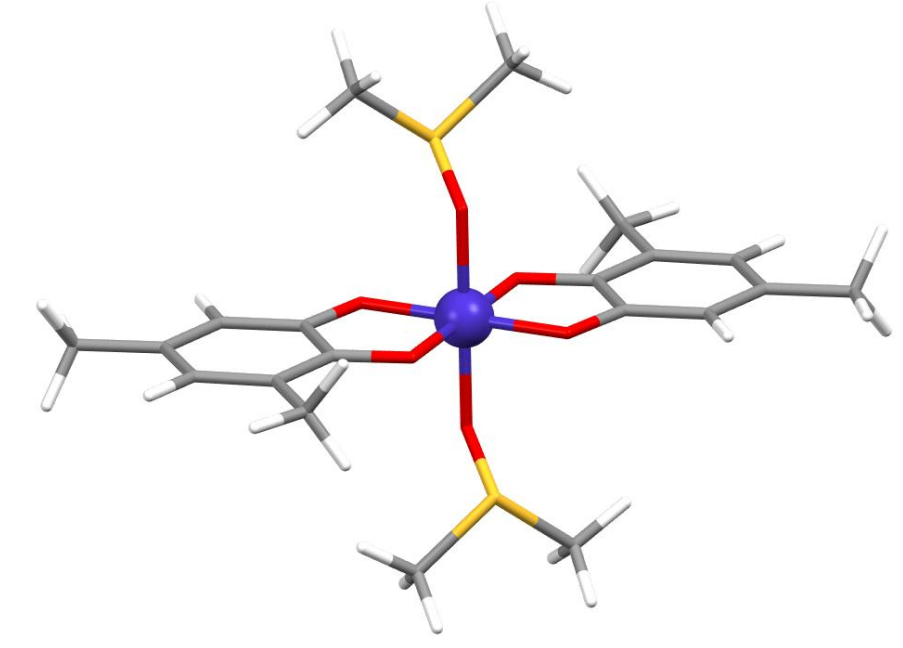




$\begin{array}{rrrl}\mathrm{H} & -0.686795 & 2.038923 & 11.268414 \\ \mathrm{H} & 1.569372 & 6.311216 & 2.749623 \\ \mathrm{H} & 0.902598 & 7.854142 & 3.413260 \\ \mathrm{H} & -0.172061 & 6.385675 & 3.263264 \\ \mathrm{H} & 0.248951 & 6.676337 & 7.119968 \\ \mathrm{H} & -0.916042 & 6.590085 & 5.729570 \\ \mathrm{H} & 0.127612 & 8.068052 & 5.972937 \\ \mathrm{H} & 4.925418 & 0.430561 & 4.202169 \\ \mathrm{H} & 5.046748 & -0.959713 & 5.350959 \\ \mathrm{H} & 6.090224 & 0.518659 & 5.592594 \\ \mathrm{H} & 3.604195 & 0.800330 & 8.571900 \\ \mathrm{H} & 5.345772 & 0.726444 & 8.058715 \\ \mathrm{H} & 4.272143 & -0.742940 & 7.910036\end{array}$




\section{References}

(1) Witt, A.; Heinemann, F. W.; Khusniyarov, M. M. Bidirectional photoswitching of magnetic properties at room temperature: ligand-driven light-induced valence tautomerism. Chem. Sci. 2015, 6 (8), 4599-4609.

(2) Schmidt, R. D.; Shultz, D. A.; Martin, J. D.; Boyle, P. D. Goldilocks Effect in Magnetic Bistability: Remote Substituent Modulation and Lattice Control of Photoinduced Valence Tautomerism and Light-Induced Thermal Hysteresis. J. Am. Chem. Soc. 2010, 132 (17), 6261-6273.

(3) Chiang, M.-C.; Hartung, W. H. Synthesis of some stilbazole derivatives. J. Org. Chem. 1945, $10(1), 21-25$.

(4) Witt, A.; Heinemann, F. W.; Sproules, S.; Khusniyarov, M. M. Modulation of Magnetic Properties at Room Temperature: Coordination-Induced Valence Tautomerism in a Cobalt Dioxolene Complex. Chem. Eur. J. 2014, 20 (35), 11149-11162.

(5) Ferreira, H.; Conradie, M. M.; Conradie, J. Electrochemical and electronic properties of a series of substituted polypyridine ligands and their Co(II) complexes. Inorg. Chim. Acta 2019, 486, 26-35.

(6) Gonglach, S.; Paul, S.; Haas, M.; Pillwein, F.; Sreejith, S. S.; Barman, S.; De, R.; Müllegger, S.; Gerschel, P.; Apfel, U.-P.; Coskun, H.; Aljabour, A.; Stadler, P.; Schöfberger, W.; Roy, S. Molecular cobalt corrole complex for the heterogeneous electrocatalytic reduction of carbon dioxide. Nat. Commun. 2019, 10 (1), 3864.

(7) Lexa, D.; Saveant, J. M. The electrochemistry of vitamin B12. Acc. Chem. Res. 1983, 16 (7), 235-243.

(8) Pierpont, C. G.; Buchanan, R. M. Transition metal complexes of o-benzoquinone, osemiquinone, and catecholate ligands. Coord. Chem. Rev. 1981, 38 (1), 45-87.

(9) Neese, F. ORCA 4.1.1 - Ab Initio, DFT and semiempirical electronic structure package. Max-Planck-Institut für Kohlenforschung, Mülheim/Ruhr, Germany

(10) Swart, M.; Ehlers, A. W.; Lammertsma, K. Performance of the OPBE exchange-correlation functional. Mol. Phys. 2004, 102 (23-24), 2467-2474.

(11) Swart, M.; Groenhof, A. R.; Ehlers, A. W.; Lammertsma, K. Validation of exchange Correlation functionals for spin states of iron complexes. J. Phys. Chem. A 2004, 108 (25), 5479-5483.

(12) Weigend, F.; Ahlrichs, R. Balanced basis sets of split valence, triple zeta valence and quadruple zeta valence quality for $\mathrm{H}$ to $\mathrm{Rn}$ : Design and assessment of accuracy. Phys. Chem. Chem. Phys. 2005, 7 (18), 3297-3305.

(13) Weigend, F. Accurate Coulomb-fitting basis sets for $\mathrm{H}$ to Rn. Phys. Chem. Chem. Phys. 2006, 8 (9), 1057-1065.

(14) Barone, V.; Cossi, M. Quantum Calculation of Molecular Energies and Energy Gradients in Solution by a Conductor Solvent Model. J. Phys. Chem. A 1998, 102 (11), 1995-2001. 